\title{
Magmatic plumbing systems of the monogenetic volcanic fields: A case study of Tolbachinsky Dol, Kamchatka
}

\author{
Yulia Kugaenko ${ }^{\mathrm{a}}$, Anna O. Volynets ${ }^{\mathrm{b}, *}$ \\ a Geophysical Survey of Russian Academy of Sciences, Kamchatka Branch, Petropavlovsk-Kamchatsky 683006, Russian Federation \\ b Institute of Volcanology and Seismology FEB RAS, Petropavlovsk-Kamchatsky 683006, Russian Federation
}

\section{A R T I C L E I N F O}

\section{Article history:}

Received 28 September 2017

Received in revised form 15 March 2018

Accepted 18 March 2018

Available online $\mathrm{xxxx}$

\section{Keywords:}

Kamchatka

Magma plumbing systems

Tolbachik

Monogenetic volcanic fields

Areal volcanism

\begin{abstract}
A B S T R A C T
Clusters of small-volume volcanoes that individually may be defined as monogenetic, but have interlinked and interconnected plumbing systems, are used to be categorized as monogenetic volcanic fields (MVF). We argue that such volcanic clusters should be distinguished as separate type of volcanism, intermediate between monogenetic and polygenetic. The magma plumbing system structure of the MVF (its complexity and polymagmatic character) is the key argument for the potential separation of them in a classification. To avoid confusion caused by genetic meaning of the used words we suggest using a term "areal volcanism" or "areal volcanic fields" (AVF instead of MVF) as defining this special type of volcanic activity. Here we provide a review of the main characteristic features of one of the largest Holocene AVF, which is active now - the Tolbachik field of cinder cones in the southern part of Klyuchevskaya volcano group (Kamchatka), known in the literature as Tolbachinsky Dol. This paper is focused on the research of magma plumbing system. We consider structural, morphological, geological, geochemical and petrological data on the erupted basalts and their genesis. Specially planned seismic experiments made in 2010-2015 (seismic tomography and microseismic sounding) allowed modeling of the principal elements of the magma plumbing system of Tolbachik AVF. Analysis of the investigations made in this area shows that Tolbachik AVF has a complex, dynamic, variable magmatic feeding system, which can be visualized as a superposition of subvertical and sublateral magma conduits. The contrast composition of the erupted rocks is caused by their different, although genetically connected, magma sources and mixing processes. One of the long-lived eruptive centers of Tolbachik AVF is Plosky Tolbachik stratovolcano, which lost its independent activity and was captured by Tolbachik AVF in Holocene. The AVF formed rejuvenated volcanism using the feeding system of the stratovolcano like an "old anthill". The magma plumbing system characteristics of Tolbachinsky Dol strongly support the idea of separation of AVF from monogenetic volcanism type in the classification.
\end{abstract}

(c) 2018 Elsevier B.V. All rights reserved.

\section{Introduction}

The interest of the research community to the enigma of monogenetic volcanism constantly increases during the last years. To some extent this is caused by the fact that small eruptive centers are less studied in comparison with the large and long-lived stratovolcanoes. But probably the main reason of this attention is the wide manifestation of this type of volcanism in the world: monogenetic volcanoes and fields of monogenetic volcanism (MVF) are described in all geodynamic environments and span practically all chemical compositions (although basaltic spectrum prevails (Connor and Conway, 2000)).

Definitions of MVF which were available from the literature up to the beginning of 2000th are not quite up to date and do not meet the modern understanding of this phenomenon among the main types of volcanism. One of the first papers defining MVF appeared at the

\footnotetext{
* Corresponding author.

E-mail addresses: ku@emsd.ru (Y. Kugaenko), a.volynets@gmail.com (A.O. Volynets).
}

beginning of XXth century, but its subject was limited to the rhyolite plateaus (Daly, 1911). The term changed its meaning with time and gained accents on the small size, large areas of distribution, absence of polygenetic edifices, clustering of the vents, similar composition of volcanic products in same area, short activity times, type of magmatic feeding, etc. (Geological dictionary, 1973; Vlodavets, 1971; Vazheevskaya, 1966, 1979; Tarakanovsky, 1978; Williams, 1950; Macdonald, 1972; Nakamura, 1977; Williams and McBirney, 1979; Greeley, 1982; Walker, 1993; Hasenaka, 1994; Takada, 1994; and many, many others). The information and data sets accumulated with time, but the idea of MVFs as clusters of monogenetic short-lived volcanoes, concentrated along the fracture zones, with primitive plumbing systems that allow quick magma supply from the upper mantle to the surface (subvertical conduits, sometimes complicated by small magma chambers) prevailed.

In XXIst century, IAVCEI initiated a Commission on Monogenetic Volcanism. Due to its activity and personal efforts of many researches, during the last decade a series of papers appeared which are dedicated to the systematization of the existing ideas of monogenetic volcanism, 
with quantitative assessments for classification of the eruptive centers. A thorough and detailed summary of the published works on volcanology, geochemistry, structural and tectonic controls, morphology and genetic relationships of the monogenetic edifices and volcanic fields is provided in Smith and Nemeth, 2017; Nemeth and Kereszturi, 2015; Canon-Tapia, 2016; etc. We address the readers to the mentioned works and references therein for the most contemporary review of research in this area of study. Probably the main achievement of the work undertaken is a new classification suggested by (Nemeth and Kereszturi, 2015), which takes into account the following parameters of the monogenetic eruptive centers: morphology of the edifice, history of the eruptive activity (amount of eruptive episodes and time spans between them), type of eruptive activity, amount of magma batches involved, volume of the single events and a total volume of the edifice and products. A very important conclusion of this work is that MVFs can't be classified either as monogenetic or polygenetic volcanism and must be considered as a transitional type between sensu stricto monogenetic and polygenetic volcanoes. Nemeth and Kereszturi (2015) emphasize several main characteristic features that distinguish MVFs. First, it is polymagmatic origin of the eruptive centers (which may be manifested by the eruption of the magmas with contrast chemical composition (within single event or as separate eruptive episodes in the same MVF) or documented in volcanic rocks geochemistry, for example as different isotopic composition of separate magma batches (McGee et al., 2015, etc.). Other frequent features of MVFs are large volume of some edifices and clustering of monogenetic edifices. It is proposed that there are long-lived and complicated magmatic plumbing systems under MVFs. The role of sublateral magma supplying structures in feeding and evolution of MVFs is still not clear. Lateral migration of magma before or during the eruptions is documented in a series of papers (Ishizuka et al., 2008; Grandin et al., 2011, González et al., 2013, Caudron et al., 2015, McGee et al., 2015, etc.). Most well-known examples of such migration are recorded for Iceland volcanoes (Einarsson and Brandsdottir, 1980; Sigmarsson et al., 2000; Sigmundsson et al., 2015), during volcanic unrest stage before submarine eruption near El Hierro island (Martí et al., 2013; González et al., 2013; García-Yeguas et al., 2014; Ibanez et al., 2012), during Manda-Hararo-Dabbahu rift activity in Ethiopia in 2005-2011 (Grandin et al., 2011; Passarelli et al., 2014) and in Lunayyir MVF in 2009 in Saudi Arabia (Pallister et al., 2010; Zobin et al., 2013; Koulakov et al., 2014, 2015). Another, fundamental, difference between MVF and polygenetic type of activity is the absence of the focused central feeding vent. Nevertheless, in some cases it is possible that the plumbing system of MVF may be focused in one channel within an expected time that is probably less than a million of years. The next stage in that case would be a growth of the polygenetic volcano. The reverse development is also possible: when a monogenetic volcanic field is superimposed to the stratovolcano, and captures the remnants of its feeding system (f. ex., Flerov and Melekestsev, 2013). For example, in Klyuchevskaya volcanic group in Kamchatka, there are two volcanic massifs composed by stratovolcanoes with superimposed fissure zones of monogenetic volcanism: Late Pleistocene - Holocene Ostry \& Plosky Tolbachik massif and Late Pleistocene - Early Holocene Krestovsky \& Ushkovsky massif (Melekestsev et al., 1991; Flerov and Ovsyannikov, 1991; Flerov et al., 2017) (Fig. 1). The latter is less studied then Tolbachinsky Dol probably due to its inactive character, but it is supposed that this massif represents the extinct analog for Tolbachik (Flerov et al., 2017). Clearly, in such complicated cases only a detailed study of the petrology, geochemistry of eruptive products integrated with the geophysical research of the feeding systems may shed light on the situation and help to distinguish an extinct stratovolcano captured by monogenetic zone from the active polygenetic volcano associated with flank parasitic vents.

In this paper, we investigate Tolbachinsky Dol in Kamchatka, Russia (Figs. 1,2) as an example to demonstrate some features of the magmatic feeding system that are not characteristic for the sensu stricto monogenetic volcanic field (sensu Nemeth and Kereszturi, 2015) or typical polygenetic volcanoes, but may be crucial to segregate monogenetic volcanic fields as a special type of volcanic activity, which we suggest to call areal volcanic fields (AVF). We review the results achieved by various methods of research which were published during the last decade and compare them with our own investigations made in this area to highlight the features that distinguish Tolbachinsky Dol as a true representative of AVF type of volcanic activity.

\section{Geological setting}

Kamchatka subduction system is located at the north-western part of the Pacific at the convergent boundary of the Okhotsk and Pacific plates. The latter is presently subducting under Kamchatka at the rate of 8-9 cm/year (DeMets et al., 1990, Scholl, 2007, and others). Quaternary volcanism in Kamchatka occurs in three zones, parallel to the trench: Eastern Volcanic Front, graben-like Central Kamchatka Depression (CKD), and Sredinny Range in the back-arc.

Kamchatka is one of the most active volcanic arcs in the world. Besides 30 active stratovolcanoes, it hosts about 20 MVFs, which are situated in the frontal, central and rear-arc parts of the arc. For example, $>250$ monogenetic edifices are situated in the Southern Kamchatka (which is geodynamically considered as a continuation of the Kurile arc), with the estimated volume of erupted products about $140 \mathrm{~km}^{3}$ (Laverov, 2005). Sredinny Range, representing the back-arc part, hosts $>1000$ monogenetic cones and lava fields, and many of them were active through Holocene despite their location about $400 \mathrm{~km}$ behind the arc front. The nature of voluminous monogenetic volcanism in Sredinny Range provokes sharp discussions, but it is poorly understood because of the remoteness of the objects. Detailed integrated studies of more accessible MVFs in CKD may provide invaluable keys for solving many of the problems with magma genesis in the back arc.

Tolbachik monogenetic volcanic field, or Tolbachinsky Dol (TD), as its southern part is usually referred to in the literature, is situated in CKD. According to the last studies, CKD is extending with a rate of 17 $\pm 3 \mathrm{~mm} / \mathrm{yr}$ over mid-late Quaternary time (Kozhurin and Zelenin, 2017). The total area of the lava plain is $875 \mathrm{~km}^{2}$ (Braitseva et al., 1984). It adjoins two stratovolcanoes (Ostry and Plosky Tolbachik) and consists of two flanks, located at the SSW and NE slopes of Plosky Tolbachik edifice. Cinder cones, formed here during the last $10 \mathrm{Ka}$, are located along the SW-NE fissure and tend to cluster (Fig. 1c): $80 \%$ of the cones are concentrated in the narrow band 3-4 km wide (Braitseva et al., 1984; Churikova et al., 2015b). TD is an ideal object for testing of the integrated models of magma plumbing systems: due to the two big eruptions happened here during the last 50 years (Great Fissure Tolbachik Eruption in 1975-76 and Tolbachik fissure eruption in 2012-2013) this area is very well studied by a variety of methods.

There are $>120$ cinder cones up to $300 \mathrm{~m}$ high (a.g.1.) in TD. They have contrast composition from high-Mg medium-K basalts to high-Al sub-alkaline basalts and basaltic andesites; there are as well basalts of transitional (intermediate) compositions (Fedotov and Markhinin, 1983; Fedotov et al., 1984; Volynets et al., 1983). During the last eruption $(2012-2013)$ about $0.67 \mathrm{~km}^{3}$ of basaltic trachyandesite with high $\mathrm{K}_{2} \mathrm{O}$ and $\mathrm{TiO}_{2}$ content were erupted for the first time in the geological history of this volcanic massif (Volynets et al., 2015). Tolbachinsky Dol crosses a stratovolcano (Plosky Tolbachik) with the similar (high$\mathrm{Mg}$ and high-Al) composition of its products (Churikova et al., 2015a). Plosky Tolbachik was formed at the beginning of Holocene and to the time of fissure eruptions of 1975 and 2012 already lost its activity (Fedotov and Markhinin, 1983; Fedotov et al., 1984; Flerov et al., 2015). There were no eruptions at the northern end of the monogenetic field during the last 2000 years (to the north from the stratovolcano edifice).

During the complex geophysical studies of the GFTE in the seventieth of the last century some features of the deep structure, the boundaries location, depths of the supposed zones of the magmatic feeding 


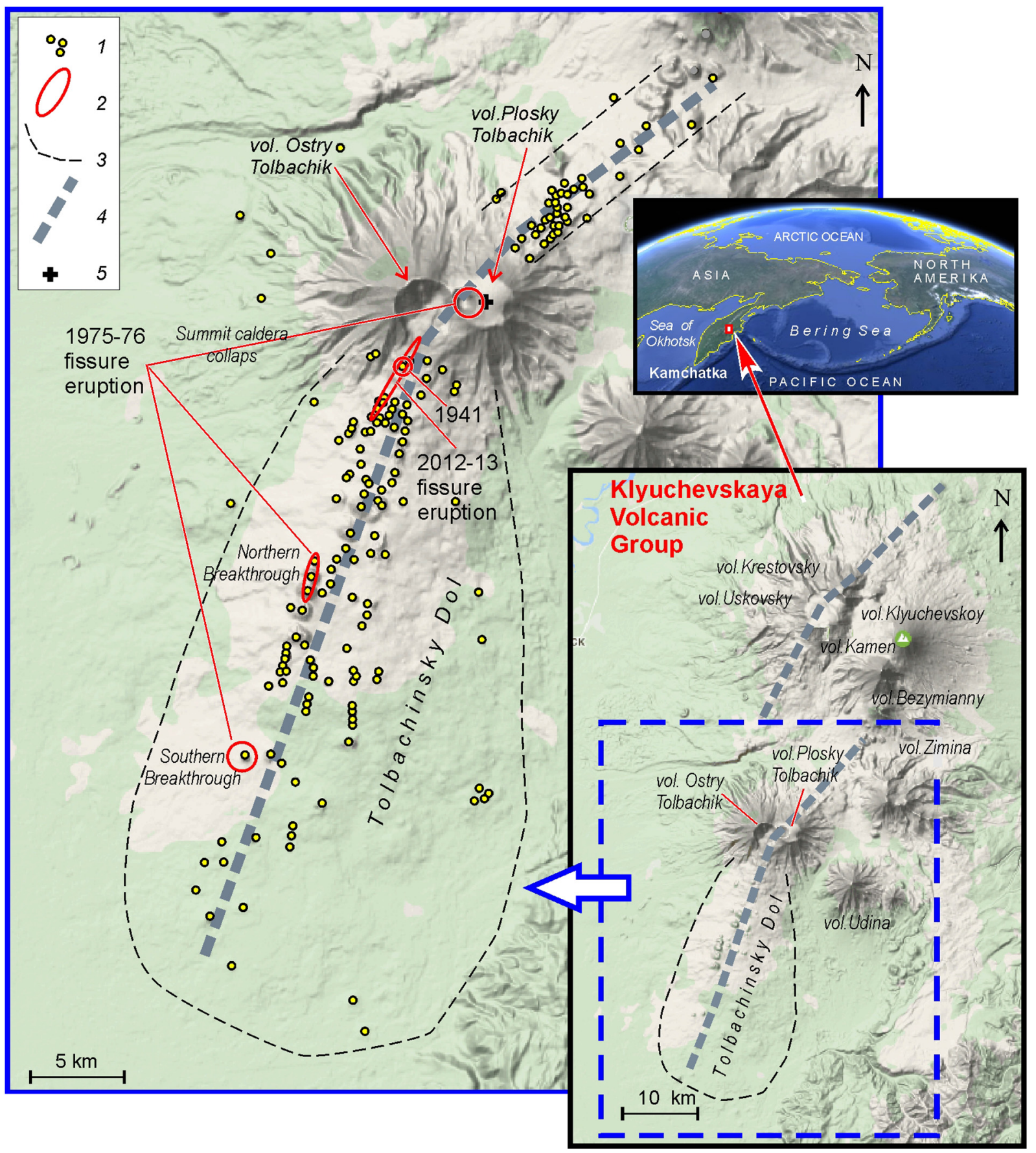

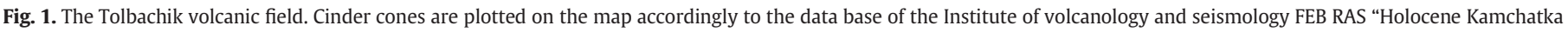

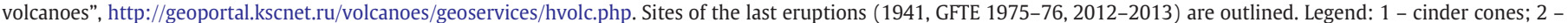
historical fissure eruptions; 3 - nominal boundary of the Tolbachik areal zone; 4 - deep fault; 5 - location of the old crater of Plosky Tolbachik stratovolcano.

and magma reservoirs were determined (Fedotov and Markhinin, 1983; Fedotov et al., 1984; Anosov et al., 1978; Balesta et al., 1977; Balesta, 1991; Zubin and Tarakanovski, 1976; Smirnov, 1979; Fedorchenko et al., 1980; and many others). The research accomplished at the beginning of the 2012-2013 eruption involved seismological, GPS and InSAR data, and resulted in the visualization of the possible location of the magmatic chamber in 2012 during the unrest stage (Ermakov et al., 2014; Fedotov et al., 2015; Kugaenko et al., 2015b; Belousov et al., 2015; Lundgren et al., 2015). (Dobretsov et al., 2016) provides the results of mineral chemistry and melt inclusion studies with the new data on the crystallization conditions in the magmatic chambers (temperature, pressure and depth) for the Tolbachik area. The 2012-2013 eruption also revived the debate on the nature of contrast composition of rocks and resulted in series of publications with new geochemical data for the products of stratovolcanoes and monogenetic activity and new models of magma generation process here (Churikova et al., 2015a; Flerov et al., 2015; Koloskov et al., 2017; Portnyagin et al., 2015; Volynets et al., 2015; etc.). Table 1 provides a summary of the characteristics of TD.

\section{The distinctive features of Tolbachinsky Dol: Review and discussion}

\subsection{Contrast composition of TD basalts and their genesis}

Tolbachinsky Dol is composed by the lavas of contrasting composition - high-Mg, medium-K basalts (hereafter high-Mg basalts), high-Al, high- 

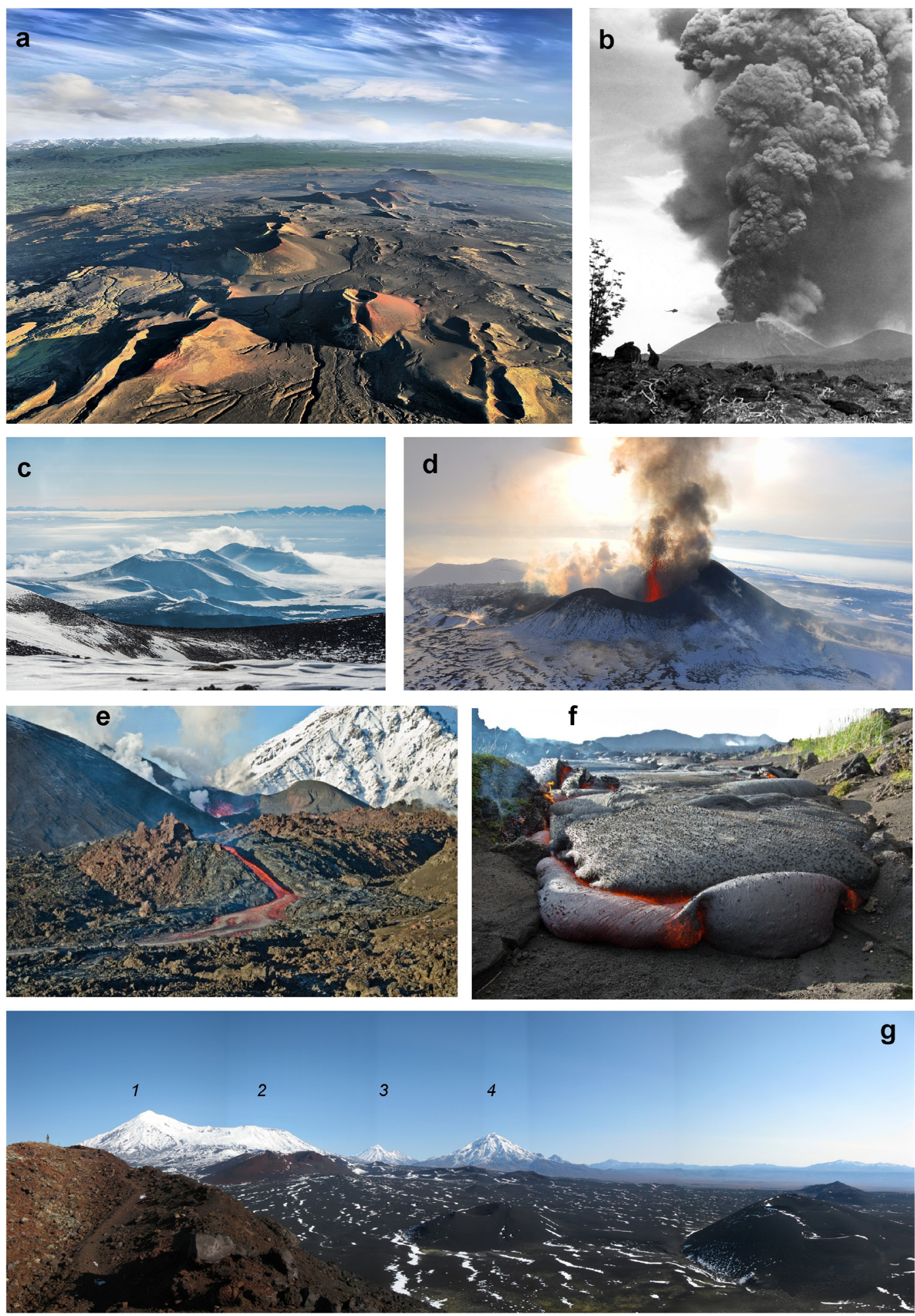

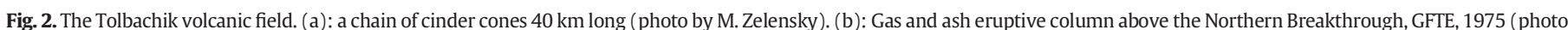

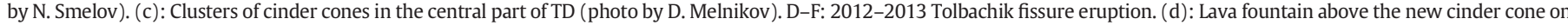

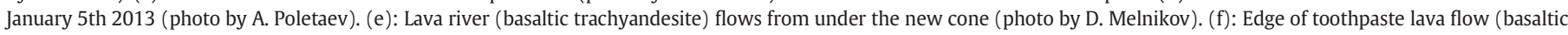

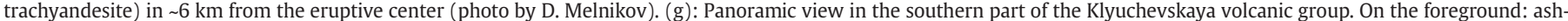
and-cinder plain and cones of Tolbachinsky Dol. On the background, volcanoes: 1 - Ostry Tolbachik, 2 - Plosky Tolbachik, 3 - Zimina, 4 - Udina (photo by Yu. Kugaenko).

K basalts and basaltic andesites (hereafter high-Al basalts), and the transitional varieties (hereafter intermediate basalts, K-rich high-Mg basalts $\mathrm{K}$-high-Mg basalts), divided by their $\mathrm{MgO} / \mathrm{Al}_{2} \mathrm{O}_{3}(>0.6,0.4-0.6$ and $<0.4)$ ratio and $\mathrm{K}_{2} \mathrm{O}$ content $(>1 \%$ and $<1 \%$ ) (after (Flerov and Bogayavlenskaya, 1983), subdivision by $\mathrm{K}_{2} \mathrm{O}$ content - after (Portnyagin et al., 2015))
(Fig. 3). The last eruption brought to the surface products with composition unique for TD - basaltic trachyandesites with high titanium and alkali content. Historical eruptions produced rocks of all mentioned types.

In 1941, during a short event at the SW slope of Plosky Tolbachik, intermediate and K-rich high-Mg basalts were erupted. 
Table 1

Basic information about Tolbachinsky Dol.

\begin{tabular}{|c|c|c|}
\hline Parameter & Description & References \\
\hline Geographic location & $\begin{array}{l}\text { Kamchatka peninsula } \\
\text { Klyuchevskaya volcanic group, south-western part }\end{array}$ & \\
\hline Tectonic position & $\begin{array}{l}\text { Central Kamchatka depression } \\
\text { SW-NE fault zone }\end{array}$ & \\
\hline Age & Holocene & Braitseva et al., 1984 \\
\hline Amount of eruptive centers & $>120$ & Braitseva et al., 1984 \\
\hline Size of the MVF & $\mathrm{S} \sim 875 \mathrm{~km}^{2}, \mathrm{~L} \sim 40 \mathrm{~km}$ & Braitseva et al., 1984 \\
\hline $\begin{array}{l}\text { Size of eruptive centers (for historical eruptions } \\
\text { only) }\end{array}$ & $\begin{array}{l}\text { GFTE 1975-1976 } \\
\text { Northern Breakthrough: } \\
\text { Cone I: } 299 \mathrm{~m} \text {, volume } 0.133 \mathrm{~km}^{3} \\
\text { Cone II: } 278 \mathrm{~m} \text {, volume } 0.099 \mathrm{~km}^{3} \\
\text { Cone III: } 108 \mathrm{~m} \text {, volume } 0.022 \mathrm{~km}^{3} \\
\text { Lava flows } 8.86 \mathrm{~km}^{2} \text {, volume } 0.22 \mathrm{~km}^{3} \\
\text { Southern breakthrough: } \\
\text { Cone I: } 165 \mathrm{~m} \text {, volume } 0.016 \mathrm{~km}^{3} \\
\text { Lava flows } 35.87 \mathrm{~km}^{2} \text {, volume } 0.97 \mathrm{~km}^{3} \\
\text { 2012-2013 eruption: } \\
\text { Naboko vents: up to } 123 \mathrm{~m} \text {, volume } 0.02 \mathrm{~km}^{3} \\
\text { Lava flows }>35 \mathrm{~km}^{2} \text {, volume } 0.55-0.65 \mathrm{~km}^{3}\end{array}$ & $\begin{array}{l}\text { Inbar et al., } 2011 \\
\text { Dvigalo et al., } 2014\end{array}$ \\
\hline Historical eruptions & $\begin{array}{ll}\text { Fissure eruptions: } & \text { Plosky Tolbachik eruptive episodes: } \\
1739-1740 & \text { Sparse data. Hawaiian type terminal activity, weak explosive events, } \\
1941 & \text { fumarole activity, and periodic presence of lava lakes inside the } \\
1975-1976 & \text { caldera. } \\
\text { (GFTE) } & 1728,1739-1740,1769,1788-1790,1793,1904,1927,1931,1937, \\
2012-2013 & 1939-41,1975-76 . \\
& \begin{array}{l}\text { According to Gushchenko (1979) - 18 eruptive episodes during } \\
\text { 1700 years. }\end{array}\end{array}$ & $\begin{array}{l}\text { Braitseva et al., } 1984 \\
\text { Churikova et al., } 2015 \text { b } \\
\text { Gushchenko, } 1979 \\
\text { Bykasov, } 2014 \\
\text { Fedotov et al., } 1991\end{array}$ \\
\hline Duration of historical eruptions & $\begin{array}{l}\text { 1739-1740 no data } \\
19411 \text { week } \\
\text { GFTE } 17 \text { months } \\
\text { 2012-2013-9 months }\end{array}$ & \\
\hline Duration of volcanic unrest prior to eruptions & $\begin{array}{l}\text { GFTE - } 9 \text { days (seismic data) } \\
2012-13 \text { eruption - up to } 7 \text { months (trustful seismic and GPS data for } 4-5 \text { months) }\end{array}$ & $\begin{array}{l}\text { Fedotov and Markhinin, } \\
1983 . \\
\text { Kugaenko et al., 2015a }\end{array}$ \\
\hline Volcanic products & $\begin{array}{l}\text { Lava, cinder, ash and bombs } \\
\text { Composition: } \\
\text { High-Mg basalts } \\
\text { High-Al basalts } \\
\text { Intermediate basalts } \\
\text { K-rich high-Mg basalts } \\
\text { Basaltic trachyandesites }\end{array}$ & $\begin{array}{l}\text { Volynets et al., } 1983 \\
\text { Churikova et al., } 2015 \mathrm{a}, \\
\text { 2015b } \\
\text { Portnyagin et al., } 2015 \\
\text { Volynets et al., } 2015\end{array}$ \\
\hline Morphology of eruptive centers & $\begin{array}{l}\text { Cinder cones } \\
\text { Lava fields } \\
\text { Eruptive fissures } \\
\text { During historical time, the Plosky Tolbachik stratovolcano is one of the eruptive centers }\end{array}$ & $\begin{array}{l}\text { Fedotov et al., } 1991 \\
\text { Flerov and Melekestsev, } 2013 \\
\text { Flerov et al., } 2015\end{array}$ \\
\hline Magma batches involved & $\begin{array}{l}\text { (1) high-Mg basalt, fractionation of primary mantle melts } \\
\text { (2) high-Al basalt to basaltic andesites and basaltic trachyandesites produced by } \\
\text { fractionation of (1), but can serve as independent magma batch, feeding the } \\
\text { eruption(s) or mixing with high-Mg melts to form intermediate basalts }\end{array}$ & Portnyagin et al., 2015 \\
\hline Volume of historical eruptions & $\begin{array}{l}19410.1 \mathrm{~km}^{3} \\
\text { 1975-1976 GFTE: } 2.18 \mathrm{~km}^{3} \\
\text { 2012-2013: } 0.65 \mathrm{~km}^{3}\end{array}$ & $\begin{array}{l}\text { Braitseva et al., } 1984 \\
\text { Dvigalo et al., } 2014 \\
\text { Belousov et al., } 2015\end{array}$ \\
\hline Total volume of erupted products & $>80 \mathrm{~km}^{3}$ & Braitseva et al., 1984 \\
\hline
\end{tabular}

During the 1975-76 Great Fissure Tolbachik eruption, three types of rocks were observed. Eruption started from the massive explosions of high-Mg basalts at the Northern Breakthrough, which lasted for $\sim 2$ month; then the center of eruption activity migrated to the south and it continued with the effusions of high-Al basalts at the Southern Breakthrough. Intermediate basalts appeared at the end of activity at the Northern Breakthrough and at its beginning at the Southern Breakthrough (Volynets et al., 1983; Fedotov and Markhinin, 1983; Fedotov et al., 1984).

In 2012-13 basaltic trachyandesites with high titanium and alkali content were erupted. Besides, during this event the migration of the activity center from the north to the south was again observed at the initial stage of the eruption. Unlike in 1975, this time composition of lavas changed mainly in terms of silica content and accompanying macroand microelement changes: together with relocation of the activity center from the Menyailov vent to the Naboko vent, $\mathrm{SiO}_{2}$ and $\mathrm{K}_{2} \mathrm{O}$ decreased, $\mathrm{MgO}, \mathrm{FeO}$ and $\mathrm{TiO}_{2}$ increased (Volynets et al., 2015). Also, the distance between the vents was much smaller in 2012 than in $1975-76$ ( $10 \mathrm{~km}$ in 1975 vs. $2.5 \mathrm{~km}$ in 2012).

There are two principal ideas of high-Mg and high-Al basalts genetic relationship, when they appear within the same volcanic structure. The first hypothesis implies that parental magmas are independent and generated at different depths, while transitional basalts are the result of their mixing at the lower levels prior to the eruption (Volynets et al., 1983; Fedotov and Markhinin, 1983; Fedotov et al., 1984; etc.) The other approach substantiates high-Mg and high-Al basalts genetic relationship as a result of the fractionation of the single high-Mg parent, producing high-Al daughter melts (as it has been shown for Klyuchevskoy volcano in (Ozerov et al., 1996; Ariskin et al., 1995; Kersting and Arculus, 1994, etc.)). Incompatible elements patterns provide arguments for both points of view (Fig. 4). From one side, the degree of fractionation between most incompatible elements ( $\mathrm{Nb}, \mathrm{Ta}$, HREE) is rather high and hard to explain within the frames of simple fractionation processes. On the other hand, high-Mg basalts, high-Al 


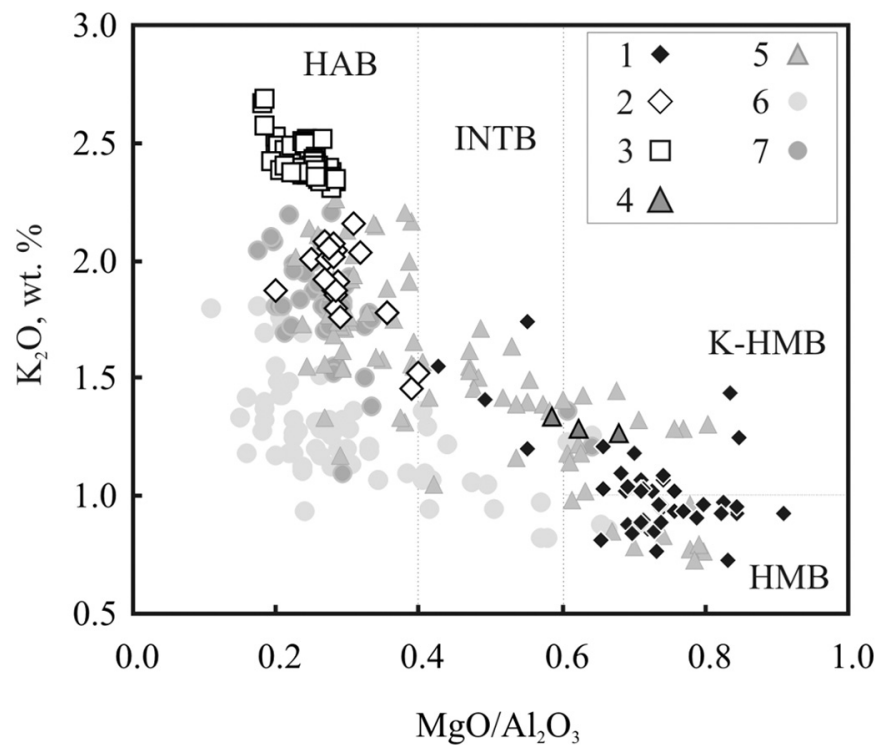

Fig. 3. Classification diagram for the Tolbachik volcanic field rocks, compared to Plosky and Ostry Tolbachik massif rocks. Boundaries and the idea of classification after (Flerov and Bogayavlenskaya, 1983), subdivision of high-Mg basalts to K-rich - after (Portnyagin et al., 2015). HMB - high-Mg basalts; K-HMB - K-rich high-Mg basalts; INTB intermediate basalts; $\mathrm{HAB}$ - high-Al basalts and basaltic andesites, including TBA (basaltic trachyandesites of 2012-2013 eruption). Legend: 1 - 1975 Northern Breakthrough basalts; 2 - 1975-1976 Southern Breakthrough basalts and basaltic andesites; 3 -basaltic trachyandesites of the 2012-2013 eruption; 4 - basalts of the 1941 eruption; 5 - volcanic rocks of the Tolbachik volcanic field, prior to the 1941 , 1975-76 and 2012-2013 eruptions; 6 - volcanic rocks forming trend 1 after (Churikova et al., 2015a) - Plosky and Ostry Tolbachik stratovolcanoes (lower parts), dikes, Plosky Tolbachik pedestal, Povorotnaya mt: 7 - volcanic rocks forming trend 2 after (Churikova et al., 2015a) - Plosky and Ostry Tolbachik stratovolcanoes (upper parts), dikes, cinder cones. Compositions of 1975-76 and 1941 volcanic rocks are from Churikova et al. (2001), Fedotov and Markhinin (1983), Fedotov et al. (1984), Portnyagin et al. (2007), (2015), Volynets et al. (1978), Volynets et al. (2000), and Tatsumi et al. (1995). Compositions of 2012-2013 rocks are from Volynets et al. (2015).

basalts and basaltic trachyandesites' patterns are practically parallel (with the exception in substantial drops of $\mathrm{Sr}$ and Eu concentrations, caused by plagioclase crystallization) and thus do not require additional sources to explain their origin and genetic relationship.

The 2012-2013 eruption provided new material for justifying the second point of view. (Volynets et al., 2015) proposed that variations in compositions of 1975-76 and 2012-13 rocks are consistent with a high degree of low pressure (100-300 MPa), nominally anhydrous fractionation of a parent melt compositionally similar to the 1975 Northern Breakthrough basalt. Geochemistry, petrological observations and modeling are in agreement with the newly erupted material being derived from remnant high-Al magma from the 1975-76 eruption with only slight amounts of cooling $\left(<1{ }^{\circ} \mathrm{C}\right.$ per year) during the intervening 36 years. The authors describe processes that caused chemical changes within the course of the 2012-2013 eruption, but do not explain in details the microelement differences between 1975 high-Mg basalt and 2012-13 basaltic trachyandesite.

Churikova et al. (2015a) provided a first detailed investigation of the petrology, geochemistry and geochronology of Plosky and Ostry Tolbachik stratovolcanoes, compared them to the monogenetic field and argued that appearance of the two geochemical trends that exist at Tolbachik massif (medium- and high-K, Fig. 3 ) is caused by the different activity of water at crystallization: from $\mathrm{H}_{2} \mathrm{O}$-saturated crystallization of high-Mg basalt to unhydrous of the sub-alkaline. According to this work, the difference in microelement concentrations in the rocks of two trends is a result of various enrichment/depletion of the same mantle source due to the upwelling.

Flerov et al. (2015) describe mineralogy and chemistry of high-Al basalts produced by Ostry and Plosky Tolbachik stratovolcanoes

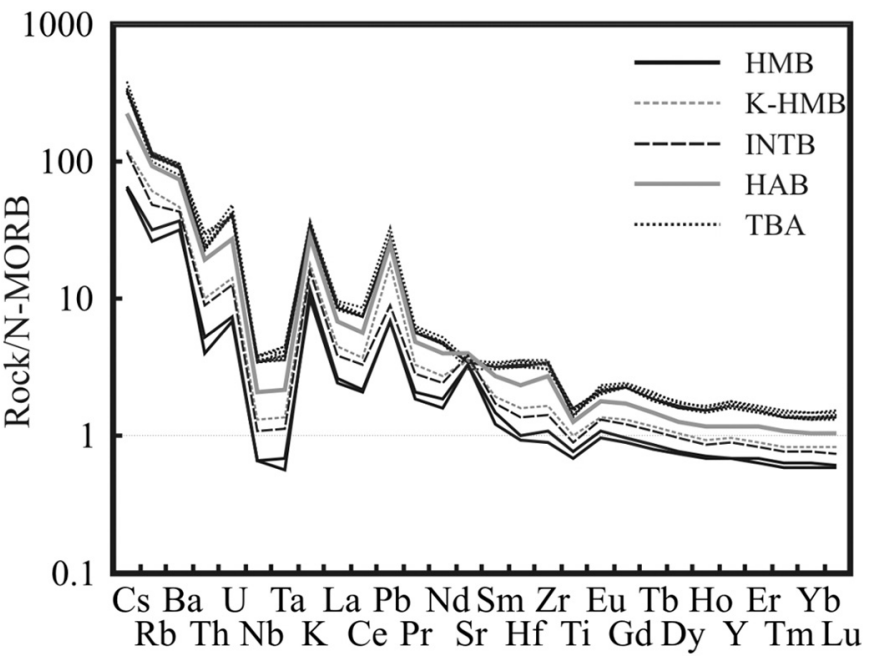

Fig. 4. N-MORB normalized incompatible trace elements patterns for the representative samples of the Tolbachik volcanic field. HMB - high-Mg basalts after Churikova et al. (2001) (sample 655-1975 Northern Breakthrough, $\mathrm{MgO}=9.77 \mathrm{wt} \%$ ) and Portnyagin et al. (2015) (sample K01-25 - Peschanye Gorki, MgO = 10.6 wt\%); K-HMB - K-rich high-Mg basalts after Portnyagin et al. (2015) (sample K01-30 - 1004 Cone, MgO = 10.3 wt\%); INTB - intermediate basalts after Portnyagin et al. (2015) (sample K01-54 Pelmen Cone, $\mathrm{MgO}=8.1$ wt\%); HAB - high-Al basalts after Churikova et al. (2001) (sample 22-8 - 1976 Southern Breakthrough, MgO = 4.41 wt\%); TBA - 2012-2013 basaltic trachyandesites after Volynets et al. (2015) ( $\mathrm{MgO}=3.02-4.42 \mathrm{wt} \%$ ). Normalization values after (Sun and McDonough, 1989).

(upper Pleistocene - 15-20 Ka), eruptions of the first stage of Holocene TD activity (10-2 Ka) and historical eruptions. They emphasize principal differences in rocks' characteristics of these three associations. Using their observations and thermobarogeochemical estimates they assume that it is impossible to produce basaltic and trachybasaltic rocks by differentiation of the same parent melt. They propose the existence of the large magma reservoir at $20-35 \mathrm{~km}$ depth and a series of smaller chambers at $0-15 \mathrm{~km}$ depth; evolution of this large reservoir at constant supply of alkaline melts from the deeper horizons provided time-spaced eruptions of high-Al, intermediate basalts and basaltic trachyandesites; they also presume the possibility of the existence of the layered mantle-crust chamber, where trachybasaltic magma assimilated basic crust material.

Koloskov et al. $(2015,2017)$ analyze petrology and isotopic composition of GFTE and 2012-13 eruption; they suggest that the main processes that influence the composition of the erupted products are (1) the melting degree of the asthenospheric mantle reservoir, and (2) mixing of melts produced by lithospheric and asthenospheric mantle sources. They do not agree with the idea of genetic relationship of the high-Al basalts of the 1975-1976 Southern Breakthrough and 2012-2013 basaltic trachyandesites. According to their opinion, the asthenospheric diapir under Central Kamchatka is one of the feeding sources for the GFTE.

A thorough analysis of the chemistry of the TD rocks is provided in (Portnyagin et al., 2015). They show that REFC processes (rechargeevacuation-fractional crystallization, after (Lee et al., 2014)) can explain all the particular characteristics of volcanic rocks in this area. According to this point of view, primary magmas, formed at $\sim 60 \mathrm{~km}$ depth, are fractionating at depths $<35 \mathrm{~km}$ in the open system with periodical replenishment by the primitive melts, followed by mixing of magmas of both types, further fractionation and, finally, eruption (s). Therefore, high-Mg basalts are the result of fractionation of the primary mantle melts. High-K high-Al basalts, which are the dominant type in TD, and basaltic trachyandesites of the last eruption are described as steadystate compositions - the products of the long-term evolution of this long-lived system and fractionation in situ. (Portnyagin et al., 2015) argue that Tolbachik geochemical characteristics meet the main criteria allowing to apply REFC processes to their genesis (which are listed as 
(1) existence of steady-state compositions and (2) their similarity to the compositions of the equilibrium crystallization; (3) dependence of REFC cycles, needed to achieve the steady-state composition, on the element distribution coefficient, and (4) potential high fractionation between the incompatible element). Transitional basalts are the result of mixing of the evolved (high-Al basalt) and primitive (high-Mg basalt) magmas. An advantage of this hypothesis is that it explains fractionation between incompatible microelements in high-Mg and high-Al basalts, which is interpreted with difficulties in the frames of the simple fractionation in the closed system. Conclusions made by (Volynets et al., 2015) do not contradict with this work - they explain part of the REFC cycle. So, here we see a conception which at certain parameters combines the models of genetic relationships, fractionation and mixing of magmas.

Therefore, the analysis of the existing petrological models shows ambiguity in the interpretation of the nature of processes which lead to the observed chemical diversity of magmas. There is also no agreement on the depth of $\mathrm{Mg}$ and $\mathrm{Al}$ magma reservoirs. At the same time, the position of most authors is more or less consistent with the concept of magma mixing processes, though they do not reach a consensus on the origin of mixing components from one or more sources.

3.2. Uneven temporal and spatial distribution of eruptive centers with different magma compositions. Superposition of AVF to the Plosky Tolbachik stratovolcano

One of the main TD features is its superposition to the Plosky Tolbachik stratovolcano. The formation of TD started at Late Pleistocene - Holocene boundary with opening of the large fissure zone. According to the petrological studies of (Churikova et al., 2015a) since that time rocks of high-K series, forming the lava plain of TD, also prevail in composition of the stratovolcano, while its lower part and basement are built by middle-K high-Mg basalts and their derivatives. Upper parts of PT (summit lavas and pyroclastics) are chemically identical to highAl basalts of TD. (Flerov and Melekestsev, 2013; Flerov et al., 2015) propose that PT already lost its activity at the beginning of Holocene and was captured by the fissure zone of monogenetic volcanism, which inherited its feeding conduits. If this indeed was the case then during the last two thousand years the stratovolcano worked as a subordinate structure - one of the eruptive centers of the regional zone of cinder cones. ${ }^{1}$ From this point of view, all eruptions happened in Holocene at the slopes of PT, including the 2012-13 eruption, are as a matter of fact the manifestation of the fissure volcanism, typical for MVF, i.e. they can't be considered as parasitical vents of the stratovolcano (Flerov and Melekestsev, 2013; Flerov et al., 2015, etc.)

The volcanic activity in Tolbachinsky Dol continues throughout Holocene. Once in several hundred years large fissure eruptions happen here, producing $>1 \mathrm{~km}^{3}$ of lava and pyroclastic deposits. The history of this area is described in details in (Braitseva et al., 1984; Churikova et al., 2015a, 2015b). It is divided to two main stages: 10-2 Ka and last $\sim 2 \mathrm{Ka}$. At the beginning of Holocene this volcanic fields was about $60 \mathrm{~km}$ long and 13-15 km wide, and the basalts were erupted around its whole area. Effusive eruptions with exclusively high-Al basaltic composition prevailed during the first stage. The second stage ( $2 \mathrm{Ka}-$ now) is principally different. The spatial distribution of the eruptive centers changed. The active area decreased in size, the northern part of the TD (to the north from PT) lost its activity. The volcanic activity was now concentrated in the narrow band only 3-4 km wide. Besides high-Al basalts, magmas with high-Mg basaltic composition appeared on the surface. Large cinder cones up to $300 \mathrm{~m}$ high a.g.l. were formed in the central part of TD, the explosivity index of the eruptions increased (sometimes up to 30-70\%). The reason of such abrupt change in the composition, style, volume and distribution of eruptions at $\sim \mathrm{Ka}$ is still under debate. The wider area involved in the eruptive process at

\footnotetext{
${ }^{1}$ As we see it, Plosky Tolbachik can be figuratively visualized as an old abandoned anthill: its internal structure permits magmas of the areal zone easily reach surface.
}

the beginning of Holocene can be explained by the end of glaciation period which enhanced the decompression effect. Activation of the deep fault, in turn, caused the appearance of more primitive high-Mg magma on the surface and grouping of the eruptive centers along the fissure zone. Studies of Churikova et al. (2015a) confirm that high-Mg middle-K magmas existed below Tolbachik zone since Pleistocene times. Therefore, observations on the evolution of the volcanic activity in TD throughout Holocene may serve as a key for understanding the changes in geodynamic environment on a larger scale.

The interesting feature of TD at the second stage of its evolution (including our time) is the uneven spatial distribution of the eruptive centers with contrast composition of magmas (Fig. 5). High-Al basalts are located in the northern part of TD and Plosky Tolbachik stratovolcano, high-Mg basalts were erupted mainly in the middle part of TD, while intermediate basalts dominate in its southern part.

So, Tolbachik VF substantially changed during Holocene both in terms of area and composition of erupted rocks.

The temporal variability of Tolbachik VF is revealed both in smaller time spans (e.g., within the last 100 years). This is shown using the examples of the historical eruptions in (Kugaenko et al., 2015b). All known historical fissure eruptions at TD were preceded and sometimes accompanied by the activation of Plosky Tolbachik stratovolcano (Fedotov and Markhinin, 1983; Fedotov et al., 1984; Kugaenko et al., 2015a,b) and increased seismic activity under it, which was interpreted as a result of magma movement in one or two peripheral magmatic reservoirs (Fedotov et al., 2011; Ermakov et al., 2014; Belousov et al., 2015)). For the last three eruptions (1941, GFTE and 2012-13) the accompanying activity of the stratovolcano decreased with each next event. These changes may confirm the assumption of the degradation of the PT feeding system under the influence of AVF.

Therefore, Tolbachik AVF is complicated by the PT edifice, which represents one of the eruptive centers of AVF during at least Late Holocene. The evolution of AVF was accompanied by the change in composition of volcanic rocks. The uneven spatial distribution of the basalts with contrast composition bears testimony on the lateral differences in the magmatic plumbing system of the AVF, while stratovolcano's feeding system is gradually degrading.

\subsection{About the structure of the magmatic plumbing system}

A SW-NE fissure zone that crosses Tolbachinsky Dol and Plosky Tolbachik edifice is concerned as the main structural element of the tectono-magmatic model of TD (Fig. 1). This structure was revealed and described by Ermakov et al. (1974) and Ermakov and Vazheevskaya (1973) as a deep fault. It was assumed that the roots of this fault lie at crust - upper mantle boundary (not $<30-35 \mathrm{~km}$ ) (Fedotov and Markhinin, 1983; Fedotov et al., 1984). Later Ermakov et al. (2014) and Ermakov and Ermakov (2006) argued for shallower depth of this fault (10-15 km) and supposed that the plane of the fault falls to the east (with the angle of incidence $75-80^{\circ}$ ). They considered this fault as a main magma conduit feeding TD.

The first model of TD plumbing system was suggested right after GFTE (Fedotov and Markhinin, 1983; Fedotov et al., 1984; Volynets et al., 1983). The eruption was accompanied by the formation of caldera at the summit of Plosky Tolbachik stratovolcano; it was supposed that the basaltic magma migration from the chamber under PT to the Southern Breakthrough area caused this event. The earthquakes swarms stretched for $50 \mathrm{~km}$ to the south from PT, indicating hidden dikes propagation and illustrating the scale of the ongoing events. The model of the magmatic feeding of GFTE eruptive centers, spatially separated along the fault, was based on the hypothesis of mixing of the melts coming from different depths and assumed that there are sublateral magma conduits (Volynets et al., 1983). The depths of magma generation and conduits locations remained controversial. The authors of this model also proposed that during the geological history of TD, strong eruptions 
I: $10-2 \mathrm{Ka}$

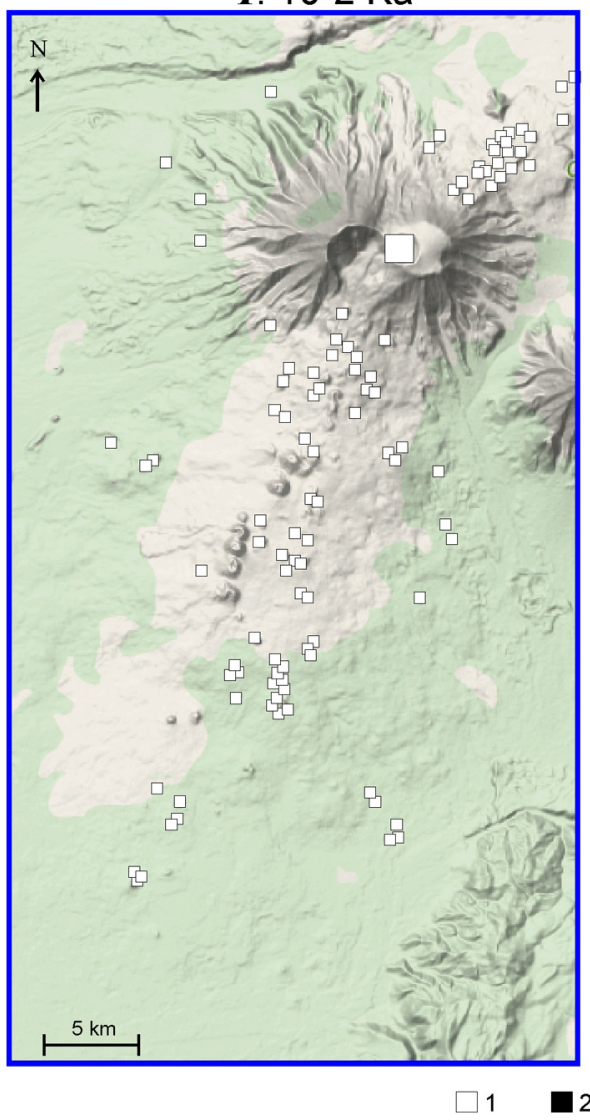

II: the last $2 \mathrm{Ka}$

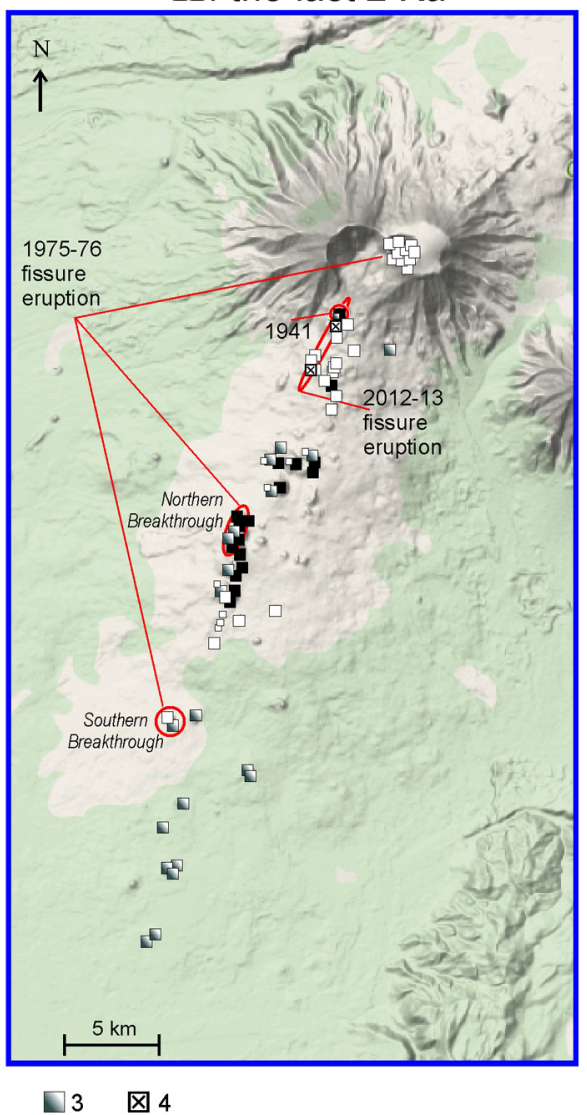

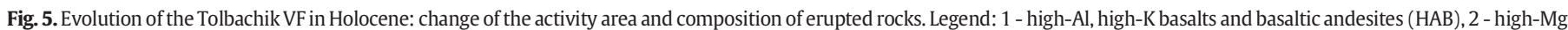
medium-K basalts (HMB); 3 - the transitional varieties (intermediate basalts - INTB); 4 - basaltic trachyandesites (TBA)

of deeply originated high-Mg basaltic magmas triggered the eruptions of high-Al basalts stored at lower crustal levels.

The development of the seismic network in Kamchatka allowed receiving better and more detailed data on the earthquakes in Klyuchevskaya volcanic group. Seismic observations in Klyuchevskaya volcanic group area started in 1946 from the installation of the seismic station in Klyuchi village ( $50 \mathrm{~km}$ from Klyuchevskoy volcano). In 1975 , at the beginning of the 1975-76 eruption, three seismic stations worked in Klyuchevskaya volcanic group area (Fedotov et al., 1984), and in 2006 there were already 12 permanent radiotelemetric seismic stations. These stations generally are equipped with short-period ( $T$ $=1.2 \mathrm{~s}$ ) 3-component seismometers SM-3 (spectral range: $0.5-20 \mathrm{~Hz}$, dynamic range: $\sim 54 \mathrm{~dB}$ ). Detailed review of seismological observation in Kamchatka is presented in (Gordeev et al., 2013; Chebrov et al., 2013). Therefore, at the beginning of the twenty first century, it became possible to use seismic tomography for the studies of the internal structure of this area.

Using seismic tomography results, geological and geophysical data, Fedotov et al. (2010) provided complex model of the deep structure of Klyuchevskaya volcanic group (Fig. 1). This model is based on the assumption that the magmatic sources and magmatic reservoirs of all volcanoes of Klyuchevskaya group are interrelated. Magma supply to the peripheral chambers and craters of the active volcanoes is carried out by long vertical channels, while monogenetic centers feeding is implemented through the fissures, which solidify after the eruptions. But the magmatic feeding of TD in this model is in accordance with the views formed in 1970-80 during GFTE research.

A tectono-magmatic model of Tolbachik areal zone was proposed by Ermakov et al. (2014). They took into account geological data, seismic tomography and the spatial distribution of the earthquakes. According to this model, the intrusions are formed in the upper wing of the inclined deep fault. This process is accompanied by the seismicity concentrated to the east from the fault axis. The magmatic sources of the monogenetic volcanism are proposed at $10-15 \mathrm{~km}$ depth b.s.l. to the north from Plosky Tolbachik and under its edifice (anomaly G-1 at Fig. 6). The model also includes the peripheral magma chambers under PT at $\sim 0$ and $\sim 3 \mathrm{~km}$ depth b.s.l.

Nevertheless, due to the weak local seismicity and remoteness from the main regional group of the seismic stations, Tolbachinsky Dol was on the periphery or even outside the area of the trustworthy modeling in the first series of the published works on the tomography of Klyuchevskaya volcanic group. Therefore, at the initial period of seismic tomography in Kamchatka this method did not bring any new data on the internal structure of TD.

After 2012-2013 eruption a new model was proposed for the magmatic system of PT and TD by Belousov et al. (2015). This model took into account the new data received during the eruption and was to some extent in agreement to the above mentioned ideas. It includes 4 magmatic reservoirs of different size and depth, which are connected by channels (Fig. 6). The existence of magmas of contrast composition is interpreted in accordance with (Portnyagin et al., 2015). This model also provides the possibility for the lateral deep migration of basalts along the rift.

However, all above hypotheses are heuristic - they are not supported by quantitative estimates.

A new stage in the investigations of the crustal structure in TD area was opened by the specially planned seismic research, as a result of which the quantitative values were received, i.e. parametric estimates of anomalies that can be related to the elements of magmatic feeding system. 

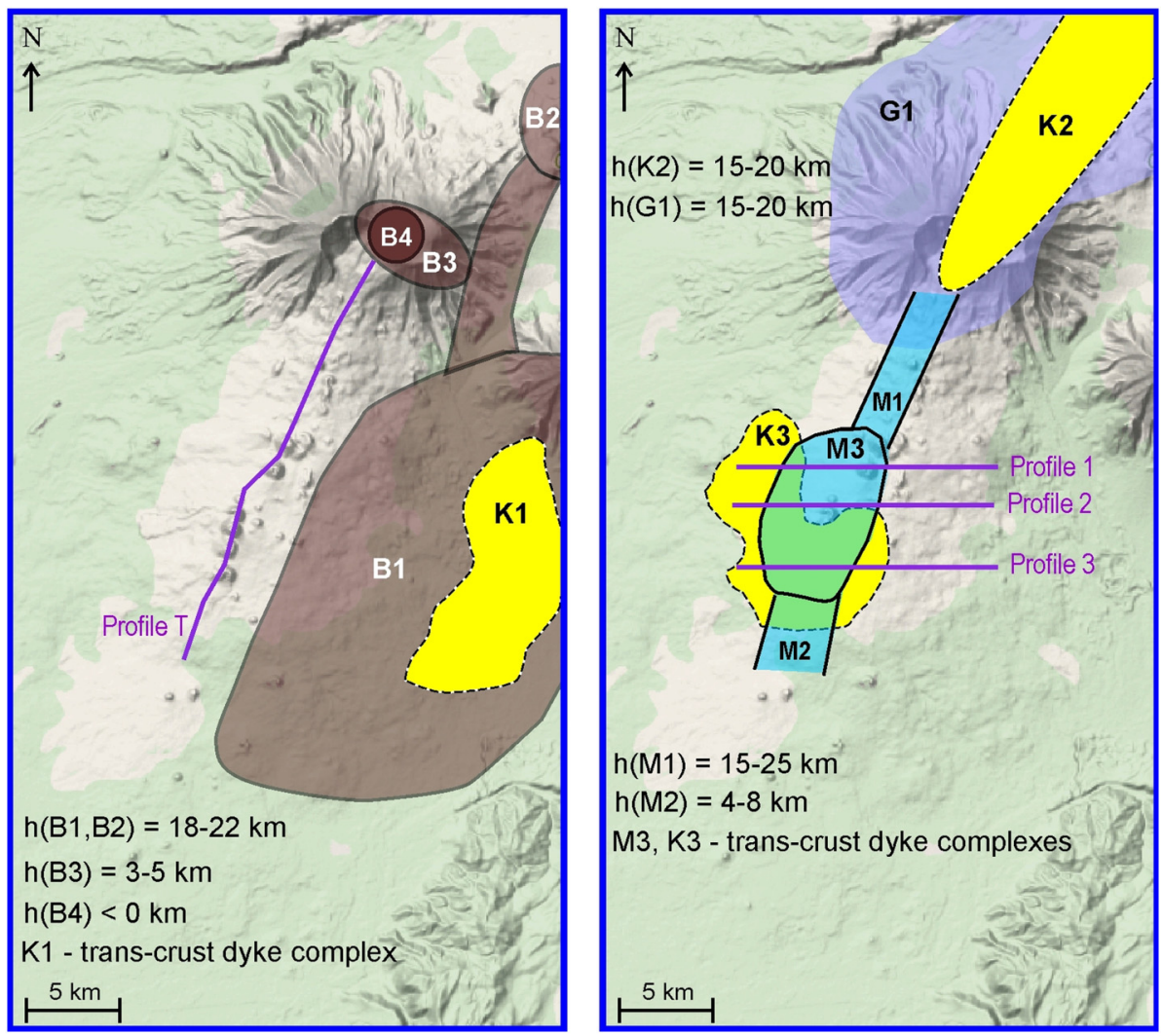

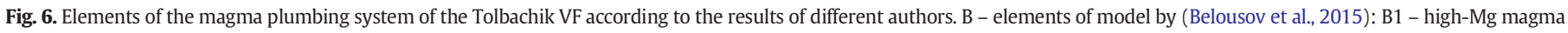

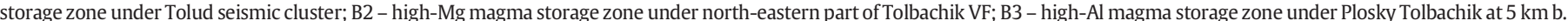

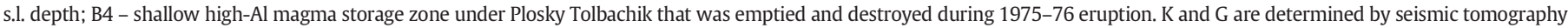

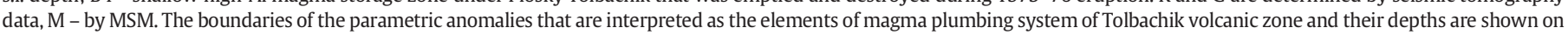

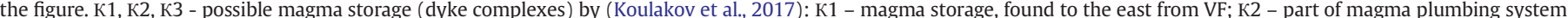

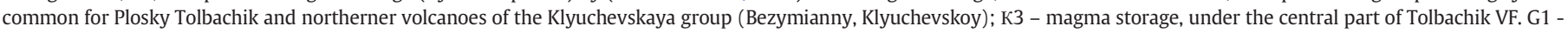

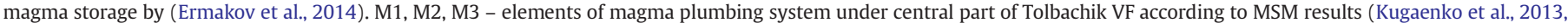

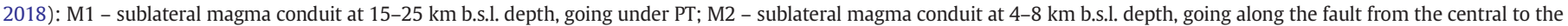

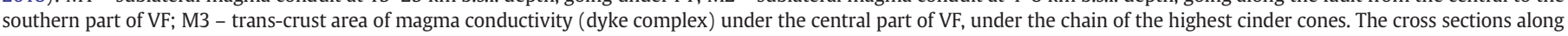
the three parallel profiles across M3 are shown at Fig. 7.

In 2014-2015, a temporal network of 30 additional seismic stations was installed in Tolbachinsky Dol area. It allowed creation of the first seismotomographic model for the southern part of Klyuchevskaya volcanic group and TD (Koulakov et al., 2017). The tomographic inversion was performed using the LOTOS code (Koulakov, 2009), which enables simultaneous inversion of the velocities of $P$ and $S$ waves and source parameters. For TD area, three spatially separated feeding sources were revealed (K-1, K-2 and K-3, Fig. 6). They are interpreted as systems of magma supplying fissures - dyke complexes. One of the sources is visualized under the central part of TD. Dyke complex responsible for PT feeding is subvertical up to $10-15 \mathrm{~km}$ b.s.l. depth, while in deeper horizons this system of fissures obliquely continues to the north and joins the feeding zone of the volcanoes of the central part of Klyuchevskoy group. This is fundamentally different from the classical views to the subvertical channels (Fedotov et al., 2010).

Starting from 2010, the investigation of the internal structure of the crust in Tolbachinsky Dol area was done by microseismic sounding method (MSM) (Gorbatikov et al., 2008, 2013, Gorbatikov and Stepanova, 2008; Gorbatikov and Tsukanov, 2011; Tsukanov and Gorbatikov, 2015; for more detailed methodology review, the readers are referred to the Supplementary materials for this paper). This method uses low-frequency ( $\mathrm{f}<1 \mathrm{~Hz}$ ) microseismic fluctuations as probing signals. They are registered step-by-step at the given points of the polygon. The survey was accomplished in $2010-2015$ at $>450$ points with $500 \mathrm{~m}$ step. It includes the central part of TD, 2012-2013 eruption area and Plosky Tolbachik edifice up to the edge of the summit caldera.
With MSM, the following elements of the magmatic feeding system of TD were revealed: (1) sub-lateral structure at 15-25 km b.s.l. depth that continues under PT (M1 at Fig. 6); (2) sub-lateral magma conduit at $4-8 \mathrm{~km}$ b.s.l. depth, going along the fault from the central to the southern part of TD (M2); large $(\sim 15-20 \mathrm{~km}$ along the fault zone and $\sim 9-10$ in the transverse direction) trans-crust magma conduction zone under central part of TD, under the chain of the highest cinder cones (M3). More detailed research of the latter heterogeneity revealed alternate magma reservoirs and feeding conduits as well as regular patterns in their location and configuration (Kugaenko et al., 2011, 2013). Fig. 7 demonstrates three vertical profiles of M3 zone, which goes through different Holocene fissures. There are relatively low speed anomalies, which can be interpreted as magma conduits or magmacontaining areas. The comparative analysis shows that the profiles are similar, with similar heterogeneities on them.

The anomalies, identified under Tolbachinsky Dol by two independent methods, are in general agreement. The anomaly under the central part of TD, where the largest cinder cones were formed, is clearly seen both in seismotomographic and MSM-profiles (K-3 and M3, Fig. 6). This may mean that in this part of Klyuchevskaya volcanic group there is a trans-crust zone where magma, most likely, exists even during the periods of prolonged absence of the eruptions. In its upper parts it may be envisaged as dyke complex. Microseismic sounding provides more detailed information on anomalies configuration and allows complementing the tomographic model with sublateral elements. Both methods of research do not reveal any substantial shallow 
magma reservoirs under Plosky Tolbachik stratovolcano, described in (Ermakov et al., 2014; Fedotov et al., 2011; Belousov et al., 2015).

Therefore most recent seismic investigations on a base of quantitative estimates show that Tolbachinsky Dol has a complicated magma plumbing system, which is a superposition of subvertical and sublateral elements, including magmatic reservoirs and feeding conduits. This system allows various ways of magma supply to the surface (Figs. 7, 8) (Kugaenko et al., 2018; Volynets and Kugaenko, 2015). Elements of the magma plumbing system differ in various segments of TD. The configuration of the magmatic system allows magma migration along monogenetic field zone and do not contradict the magma mixing model, which is a base for some of the petrogenetic models for basalts of TD.

\section{Conclusions}

The understanding of the nature of monogenetic volcanic fields is in constant progress.

Tolbachinsky Dol, one of the well-studied monogenetic volcanic fields, has several distinctive features, which are not typical for separate monogenetic edifices or polygenetic volcanoes. First and most important, TD has a complicated, dynamic, variable magmatic plumbing system. It is worth to list here the main features of TD and its magmatic plumbing system:

(1) Spatial concentration of the eruptive centers along the elongated zone of the deep fault and clustering of the monogenetic edifices;

(2) Polymagmatic genesis of separate eruptive centers (eruption of the magmas with contrast composition and/or multiple sources involved in magma generation). High-Mg basalts are produced by fractionation of the primary mantle melts; high-K high-Al basalts and basaltic trachyandesites of 2012-2013 eruption are the result of the long-term evolution of this magmatic system, with fractionation of $\mathrm{Mg}$ basaltic magmas in situ, while basalts with intermediate composition are produced by mixing between high-Al and high-Mg basalts.

(3) Uneven spatial distribution of eruptive centers of different composition.

(4) Temporal variability of volcanic activity in Tolbachinsky Dol.

(5) Tolbachinsky Dol is superimposed to Plosky Tolbachik stratovolcano. Most likely, in Holocene PT serves as one of the eruptive centers of the areal volcanic field. Geophysical data confirm its subordinate role with respect to the superimposed areal volcanic field.

(6) New instrumental seismic data allow us to complement and detail the model of Tolbachinsky Dol magma plumbing system, on a base of quantitative estimates. The results of the microseismic sounding (2010-2015) and detailed seismic tomography experiment (2014-2015) revealed parametric anomalies which can be interpreted as elements of the magma plumbing system. Tolbachinsky Dol has a complicated magma plumbing system, which can be visualized as a superposition of subvertical and sublateral magma conduits. Our research reveals a system of independent magma conduits and magmatic reservoirs. Finally, there are no pronounced subvertical channels above the crystalline basement level. This conclusion contradicts the existing ideas of simple subvertical magma supplying channels, feeding the monogenetic centers. Petrological data confirm the existence of the complicated magmatic system with mantle feeding and open fractionation in the crustal reservoirs.

(7) Characteristics of Tolbachik volcanic field strongly support the separation of MVFs from monogenetic and polygenetic

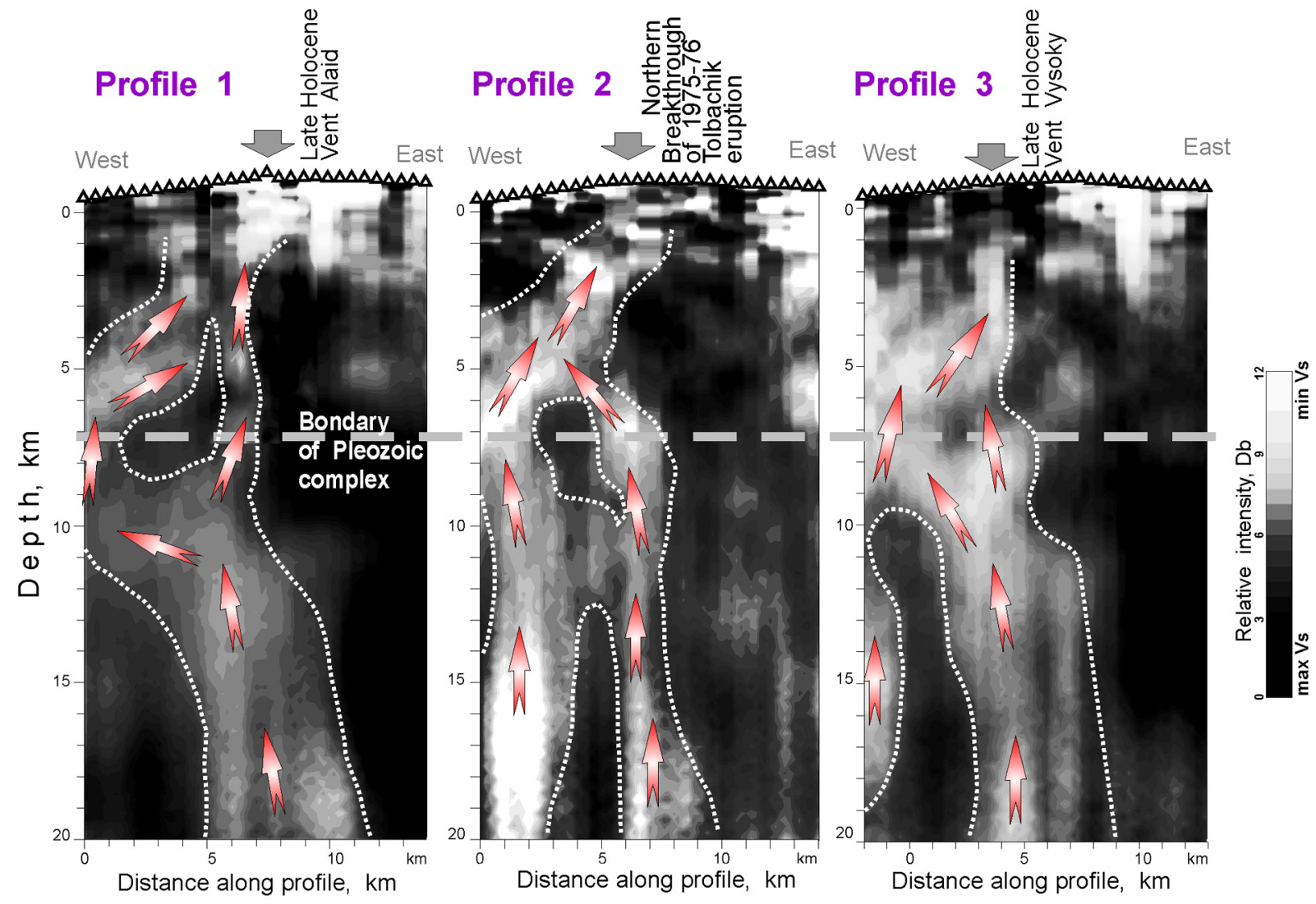

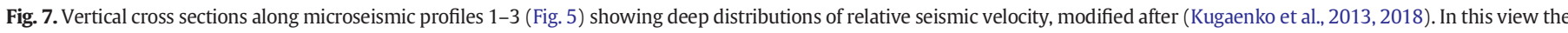

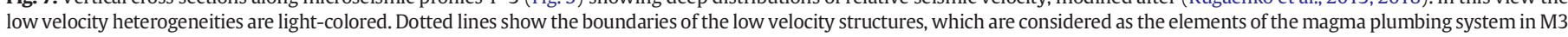
zone at Fig. 5. Most light-colored areas are interpreted as magma storage zones. Arrows show probable paths for basaltic magma movement to the surface. 


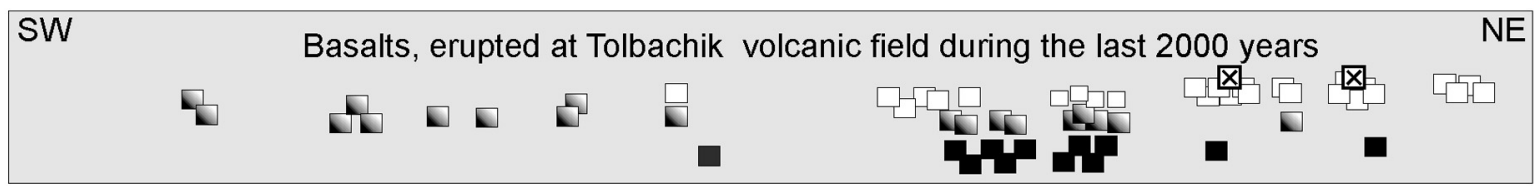

Basalts, erupted at Tolbachik volcanic field during the last 2000 years

Plosky

Tolbachik Volcanic Field

Tolbachik

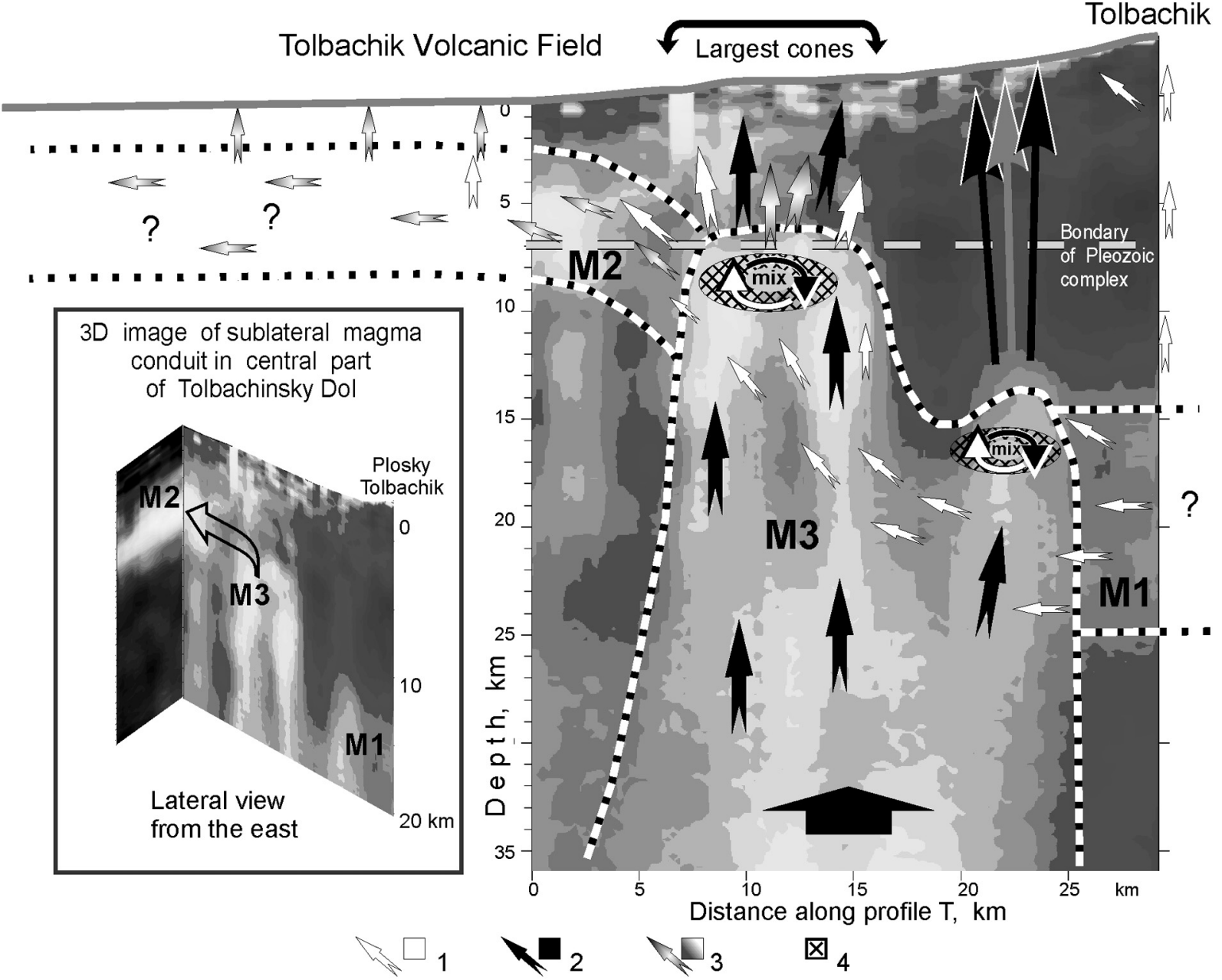

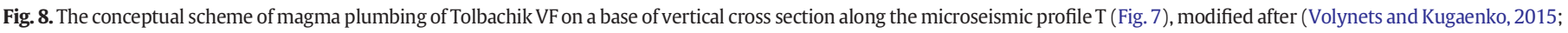

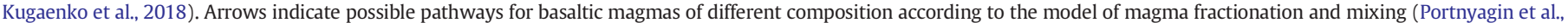
2015). The scheme provides possible explanation for the uneven spatial distribution of the basalts of different composition in Tolbachik VF. Legend as at Fig. 5.

volcanoes in classification suggested by (Nemeth and Kereszturi, 2015) (Table 2). In Russian (mainly, but not exclusively) literature there is a special term for this type of volcanic activity "areal volcanism" (for example, Vlodavets, 1971; Vazheevskaya, 1966, 1979; Tarakanovsky, 1978, etc.). Taking into account all the facts stated above, which come into conflict with the definition of the monogenetic volcanism sensu stricto, we believe it might be prudent to accept term "areal volcanism" or "areal volcanic fields" (AVF instead of MVF) as defining this special type of volcanic activity, because it allows eliminating confusion caused by genetic meaning of the used words. The term "areal" emphasizes the spatial distribution of a phenomenon of a certain type on the earth surface. That allows applying it to clusters of small-volume volcanoes, where each volcano is formed as a result of a single eruptive episode, but the geochemical features of the erupted lavas indicate their genetic affinity, caused by the interlinked and interconnected plumbing systems of these eruptive centers.

Table 2

Principal reasons for classification of AVF as a special type of volcanism based on Tolbachinsky Dol example.

\begin{tabular}{|c|c|c|c|c|c|}
\hline & $\begin{array}{l}\text { Composition } \\
\text { of magma }\end{array}$ & $\begin{array}{l}\text { Type of volcanic } \\
\text { edifices in the field }\end{array}$ & $\begin{array}{l}\text { Areal distribution of } \\
\text { eruptive centers }\end{array}$ & $\begin{array}{l}\text { Polygenetic } \\
\text { volcanic edifices }\end{array}$ & Magmatic plumbing system \\
\hline $\begin{array}{l}\text { Monogenetic volcanic fields in the old } \\
\text { classification }\end{array}$ & Constant & Monogenetic & $\begin{array}{l}\text { Separate eruptive } \\
\text { centers }\end{array}$ & Absent & Primitive \\
\hline $\begin{array}{l}\text { Tolbachinsky Dol - a possible example of the } \\
\text { areal volcanic field }\end{array}$ & Contrast & $\begin{array}{l}\text { Monogenetic and } \\
\text { polygenetic }\end{array}$ & $\begin{array}{l}\text { Clustering of } \\
\text { eruptive centers }\end{array}$ & $\begin{array}{l}\text { Present and } \\
\text { captured by AVF }\end{array}$ & $\begin{array}{l}\text { Complex system of subvertical and } \\
\text { sublateral magma conduits }\end{array}$ \\
\hline
\end{tabular}


Therefore, integration of various methods in volcanic fields' studies allows avoiding ambiguity in the interpretation of the results. While the investigations of Tolbachik AVF continue, we would like to emphasize the importance of the multidisciplinary approach as the main instrument to create trustful models of the processes hidden in the depths.

\section{Acknowledgements}

We thank our two reviewers for the detailed and helpful comments on the earlier version of this manuscript. This work is supported by the Institute of volcanology and seismology FEB RAS (theme \# 0282-20160004), Kamchatka Branch of Geophysical Survey RAS, and by RFBR grant \# 17-05-00112.

\section{Appendix A. Supplementary data}

Supplementary data to this article can be found online at https://doi. org/10.1016/j.jvolgeores.2018.03.015.

\section{References}

Anosov, G.I., Bikkenina, S.L., Popov, A.A., Sergeev, K.F., Fedorchenko, V.I., Utnasin, V.K. 1978. Glubinnoe seismicheskoe zondirovanie Kamchatki. Nauka, Moscow (130 p. in Russian).

Ariskin, A.A., Barmina, G.S., Ozerov, A. Yu, et al., 1995. Genesis of high-alumina basalts from Klyuchevskoi volcano. Petrology 3 (5), 496-521.

Balesta, S.T., 1991. Earth crust structure and magma chambers of the areas of present Kamchatka volcanism. In: Fedotov, S.A., Masurenkov, Y.P. (Eds.), Active Volcanoes of Kamchatka. Nauka, Moscow, pp. 36-45.

Balesta, S.T., Kargopol'tsev, A.A., Grigorian, G.B., 1977. Seismicheskoe prosvechivanie Novih Tolbachinskih vulkanov na Kamchatke. DAN USSR 237 (2), 412-415 (in Russian).

Belousov, A., Belousova, M., Edwards, B., Volynets, A., Melnikov, D., 2015. Overview of the precursors and dynamics of the 2012-13 basaltic fissure eruption of Tolbachik volcano, Kamchatka, Russia. J. Volcanol. Geotherm. Res. 299:19-34. https://doi.org/ 10.1016/j.jvolgeores.2015.04.009.

Braitseva, O.A., Melekestsev, I.V., Flerov, G.B., Ponomareva, V.V., Sulerzhitsky, L.D., Litasova, S.N., 1984. Holocene volcanism of the Tolbachik regional zone of cinder cones. In: Fedotov, S.A. (Ed.), Great Tolbachik Fissure Eruption, Kamchatka, 1975-1976. Nauka, Moscow, pp. 177-209 (In Russian).

Bykasov, V.E., 2014. The 1739 and 1740 eruptions in Plosky Tolbacik area. Proceedings of the Annual Conference on Volcanologists Day "Volcanism and Related Processes". IVS FEB RAS, Petropavlovsk-Kamchatsky :pp. 14-21 (In Russian). http://www.kscnet.ru/ ivs/publication/volc_day/2014/art2.pdf.

Canon-Tapia, E., 2016. Reappraisal of the significance of volcanic fields. J. Volcanol. Geotherm. Res. 310:26-38. https://doi.org/10.1016/j.jvolgeores.2015.11.010.

Caudron, C., Taisne, B., Kugaenko, Yu., Saltykov, V., 2015. Magma migration at the onset of the 2012-13 Tolbachik eruption revealed by seismic amplitude ratio analyses. J. Volcanol. Geotherm. Res. 307:60-66. https://doi.org/10.1016/j. volgeores.2015.09.010.

Chebrov, V.N., Droznin, D.V., Kugaenko, Yu.A., Levina, V.I., Senyukov, S.L., Sergeev, V.A., Schevchenko, Yu.V., Yaschuk, V.V., 2013. The system of detailed seismological observations in Kamchatka. J. Volcanol. Seismol. 7 (1):16-36. https://doi.org/10.1134/ S0742046313010028.

Churikova, T., Dorendorf, F., Woerner, G., 2001. Sources and fluids in the mantle wedge below Kamchatka, evidence from across-arc geochemical variation. J. Petrol. 42: 1567-1593. https://doi.org/10.1093/petrology/42.8.1567.

Churikova, T.G., Gordeychik, B.N., Iwamori, H., Nakamura, H., Ishizuka, O., Nishizawa, T., Haraguchi, S., Miyazaki, T., Vaglarov, B.S., 2015a. Petrological and geochemical evolution of the Tolbachik volcanic massif, Kamchatka, Russia. J. Volcanol. Geotherm. Res. 307:156-181. https://doi.org/10.1016/j.jvolgeores.2015.10.026.

Churikova, T.G., Gordeychik, B.N., Edwards, B.R., Ponomareva, V.V., Zelenin, E.A., 2015b. The Tolbachik volcanic massif: a review of the petrology, volcanology and eruption history prior to the 2012-2013 eruption. J. Volcanol. Geotherm. Res. 307:3-21. https://doi.org/10.1016/j.jvolgeores.2015.10.016.

Connor, C.B., Conway, F.M., 2000. Basaltic volcanic fields. In: Sigurdsson, H. (Ed.), Encyclopedia of Volcanoes. Academic Press, San Diego, pp. 331-343.

Daly, R.A., 1911. The nature of volcanic action. P. Am. Acad. Arts Sci. 47 (3), 47-122.

DeMets, C., Gordon, R., Argus, D., Stein, S., 1990. Current plate motions. Geophys. J. Int. $101,425-478$

Dobretsov, N.L., Simonov, V.A., Kotlyarov, A.V., Karmanov, N.S., Kulakov, R.Y., 2016. Physicochemical parameters of crystallization of melts in intermediate suprasubduction chambers (by the example of Tolbachik and Ichinskii volcanoes, Kamchatka Peninsula). Russ. Geol. Geophys. 57 (7), 993-1015

Dvigalo, V.N., Svirid, I.Yu., Shevchenko, A.V., 2014. The first quantitative estimates of parameters for the Tolbachik fissure eruption of 2012-2013 from aerophotogrammetric observations. J. Volcanol. Seismol. 8 (5):261-268. https://doi.org/10.1134/ S0742046314050029.
Einarsson, P., Brandsdottir, B., 1980. Seismological evidence for lateral magma intrusion during the July 1978 deflation of the Krafla volcano in NE-Iceland. J. Geophys. 47 $160-165$.

Ermakov, V.A., Ermakov, A.V., 2006. Geological-petrological models of the 1975-1976 eruption at Tolbachinsky Dol (Klyuchevskaya volcanic group). J. Geophys. Res. 5, 53-115 (in Russian).

Ermakov, V.A., Vazheevskaya, A.A., 1973. Ostry and Plosky Tolbachik volcanoes. Bull. Volcanologicheskih Stantsij AN SSSR 49, 36-43 (in Russian).

Ermakov, V.A., Milanovsky, E.E., Tarakanovsky, A.A., 1974. The meaning of riftogenesis in the formation of the Quaternary volcanic zones of Kamchatka. Mosc. Univ. Geol. Bull. 3, 3-20 (in Russian).

Ermakov, V.A., Gontovaya, L.I., Senyukov, S.L., 2014. Tectonics and magma chambers of the recent Tolbachik fissure eruption (Kamchatka peninsula). Izv. Atmos. Oceanic Phys. 50 (8), 745-765.

Fedorchenko, I.A., Titlinov, V.S., Skachkov, P.P., Alekseev, V.A., 1980. Electromagnetic in duction sounding in the Great Tolbachik fissure eruption area. J. Volcanol. Seismol. 2, 112-118 (in Russian with English abstract).

Fedotov, S.A., Markhinin, Y.K., 1983. The Great Tolbachik Fissure Eruption; Geological and Geophysical Data 1975-1976. Cambridge Univ. Press, Cambridge, United Kingdom (353 pp.).

Fedotov, S.A., Flerov, G.B., Chirkov, A.M. (Eds.), 1984. The 1975-1976 Large Tolbachik Fissure Eruption in Kamchatka. Nauka, Moscow (in Russian with English abstract).

Fedotov, S.A., Balesta, S.T., Dvigalo, V.N., Razina, A.A., Flerov, G.B., Chirkov, A.M., Fedotov, S.A., Balesta, S.T., Masurenkov, Yu P., 1991. New Tolbachik volcanoes. Active Volcanoes of Kamchatka. vol. 1. Nauka, Moscow, pp. 214-279 (in Russian with English abstract).

Fedotov, S.A., Zharinov, N.A., Gontovaya, L.I., 2010. The magmatic system of the Klyuchevskaya group of volcanoes inferred from data on its eruptions, earthquakes, deformation, and deep structure. J. Volcanol. Seismol. 4, 3-35.

Fedotov, S.A., Utkin, I.S., Utkina, L.I., 2011. The peripheral magma chamber of Ploskii Tolbachik, a Kamchatka basaltic volcano: activity, location and depth, dimensions, and their changes based on magma discharge observations. J. Volcanol. Seismol. 5 (6):369-385. https://doi.org/10.1134/S0742046311060042.

Fedotov, S.A., Slavina, L.B., Kuchay, M.S., Senyukov, S.L., 2015. Seismic processes and migration of magma during the Great Tolbachik fissure eruption of 1975-1976 and Tolbachik fissure eruption of 2012-2013, Kamchatka peninsula. Izv. Atmos. Oceanic Phys. 51 (7), 667-687.

Flerov, G.B., Bogayavlenskaya, G.Ye, 1983. Geology and petrochemistry of the Tolbachik regional zone of cinder cones. In: Fedotov, S.P., Markhinin, Ye.K (Eds.), The Great Tolbachik Fissure Eruption: Geological and Geophysical Data 1975-1976 Cambridge Earth Science Series. Cambridge University Press, Cambridge, pp. 96-115.

Flerov, G.B., Melekestsev, I.V., 2013. 2012-2013 eruption as a result of ongoing activity of Tolbachik regional field of cinder cones (Kluchevskaya group of volcanoes, Kamchatka). Proceedings of the Annual Conference on Volcanologists Day "Volcanism and Related Processes". IVS FEB RAS, Petropavlovsk-Kamchatsky (In Russian). http://www.kscnet.ru/ivs/publication/volc_day/2013/art20.pdf.

Flerov, G.B., Ovsyannikov, A.A., 1991. Ushkovsky volcano. In: Fedotov, S.A., Masurenkov, Yu.P. (Eds.), Active Volcanoes of Kamchatka. vol. 1. Nauka, Moscow, pp. 164-165.

Flerov, G.B., Anan'ev, V.V., Ponomarev, G.P., 2015. The petrogenesis of rocks of the Ostryi and Ploskii volcanoes and the relationship between volcanic occurrences of basaltic and trachybasaltic magmas in the Tolbachik Dol area, Kamchatka. J. Volcanol. Seismol. 9 (3):162-181. https://doi.org/10.1134/S0742046315030021.

Flerov, G.B., Churikova, T.G., Anan'ev, V.V., 2017. The Ploskie Sopki volcanic massif: geology, petrochemistry, mineralogy, and petrogenesis (Klyuchevskoi volcanic cluster Kamchatka). J. Volcanol. Seismol. 11 (4):266-284. https://doi.org/10.1134/ S0742046317040030.

García-Yeguas, A., Ibáñez, J.M., Koulakov, I., Jakovlev, A., Romero-Ruiz, M.C., Prudencio, J. 2014. Seismic tomography model reveals mantle magma sources of recent volcanic activity at El Hierro Island (Canary Islands, Spain). Geophys. J. Int. 199 (3): 1739-1750. https://doi.org/10.1093/gji/ggu339.

Geological dictionary, 1973. Moscow: Nedra. vol. 1. (486 p.)

González, P.J., Samsonov, S.V., Pepe, S., Tiampo, K.F., Tizzani, P., Casu, F., Fernández, J. Camacho, A.G., Sansosti, E., 2013. Magma storage and migration associated with the 2011-2012 El Hierro eruption: implications for crustal magmatic systems at oceanic island volcanoes. J. Geophys. Res. Solid Earth 118:4361-4377. https://doi.org/ 10.1002/jgrb.50289.

Gorbatikov, A.V., Stepanova, M.Yu, 2008. Statistical characteristics and stationarity properties of low-frequency seismic signals. Izv. Phys. Solid Earth 4 (1), 50-59.

Gorbatikov, A.V., Tsukanov, A.A., 2011. Simulation of the Rayleigh waves in the proximity of the scattering velocity heterogeneities. Exploring the capabilities of the microseismic sounding method. Izv. Phys. Solid Earth 47 (4), 354-369.

Gorbatikov, A.V., Stepanova, M.Yu., Korablev, G.E., 2008. Microseismic field affected by local geological heterogeneities and microseismic sounding of the medium. Izv Phys. Solid Earth 44 (7), 577-592.

Gorbatikov, A.V. Montesinos, F.G., Arnoso, J. Stepanova, M.Yu, Benavent, M. Tsukanov, A.A., 2013. New features in the subsurface structure model of El Hierro Island (Canaries) from low-frequency microseismic sounding. An insight into the 2011 seismovolcanic crisis. Surv. Geophys. 34 (4):463-489. https://doi.org/10.1007/s10712-0139240-4

Gordeev, E.I., Fedotov, S.A., Chebrov, V.N., 2013. Detailed seismological investigations in Kamchatka during the 1961-2011: main results. J. Volcanol. Seismol. 7 (1):1-15. https://doi.org/10.1134/S0742046313010041.

Grandin, R., Jacques, E., Nercessian, A., Ayele, A., Doubre, C., Socquet, A., Keir, D., Kassim, M., Lemarchand, A., King, G.C.P., 2011. Seismicity during lateral dike propagation: insights from new data in the recent Manda Hararo-Dabbahu rifting episode (Afar, Ethiopia) Geochem. Geophys. Geosyst. 12 (Q0AB08). https://doi.org/10.1029/2010GC003434. 
Greeley, R., 1982. The Snake River Plain, Idaho: representative of a new category of volcanism. J. Geophys. Res. Solid Earth 87 (B4), 2705-2712.

Gushchenko, I.I., 1979. Eruptions of World Volcanoes. Cataligue. Nauka, Moscow (475 pp.).

Hasenaka, T., 1994. Size, distribution, and magma output rate for shield volcanoes of the Michoacán-Guanajuato volcanic field, Central Mexico. J. Volcanol. Geotherm. Res. 63 (1-2), 13-31.

Ibanez, J.M., De Angelis, S., Diaz-Moreno, A., Hernandez, P., Alguaci, G., Posadas, A., Perez, N., 2012. Insights into the 2011-2012 submarine eruption off the coast of El Hierro (Canary Islands, Spain) from statistical analyses of earthquake activity. Geophys. J. Int. 191 (2), 659-670.

Inbar, M., Gilichinsky, M., Melekestsev, I., Melnikov, D., Zaretskaya, N., 2011. Morphometric and morphological development of Holocene cinder cones: a field and remote sensing study in the Tolbachik volcanic field, Kamchatka. J. Volcanol. Geotherm. Res. 201 (1):301-311. https://doi.org/10.1016/j.jvolgeores.2010.07.013.

Ishizuka, O., Geshi, N., Itoh, J.I., Kawanabe, Y., TuZino, T., 2008. The magmatic plumbing of the submarine Hachijo NW volcanic chain, Hachijojima, Japan: long-distance magma transport. J. Geophys. Res. Solid Earth 113 (B8). https://doi.org/10.1029/ 2007JB005325.

Kersting, A.B., Arculus, R.J., 1994. Klyuchevskoy volcano, Kamchatka, Russia: the role of high-flux recharged, tapped, and fractionated magma chamber(s) in the genesis of high- $\mathrm{Al}_{2} \mathrm{O}_{3}$ from high-MgO basalt. J. Petrol. 35 (1), 1-41.

Koloskov, A.V., Davydova, M.Y., Izbekov, P.E., Ananyev, V.V., Kandrin, A.A., 2015. Evolution of rock compositions observed during the 2012-2013 eruptions of the New Tolbachik volcanoes: online mantle control. J. Pac. Geol. 9:338-358. https://doi.org/10.1134/ S1819714015050036.

Koloskov, A.V., Davydova, M.Yu., Anan'ev, V.V., Kandrin, A.A., 2017. The Tolbachik volcanic center: the composition of ejecta, phases of activity, a petrologic model. J. Volcanol. Seismol. 11 (4):235-265. https://doi.org/10.1134/S0742046317040042.

Koulakov, I., 2009. LOTOS code for local earthquake tomographic inversion: benchmarks for testing tomographic algorithms. BSSA 99 (1):194-214. https://doi.org/10.1785/ 0120080013.

Koulakov, I., El Khrepy, S., Al-Arifi, N., Sychev, I., Kuznetsov, P., 2014. Evidence of magma activation beneath the Harrat Lunayyir basaltic field (Saudi Arabia) from attenuation tomography. J. Geophys. Res. Solid Earth 5 (2):873. https://doi.org/10.5194/se-5-873-2014.

Koulakov, I., El Khrepy, S., Al-Arifi, N., Kuznetsov, P., Kasatkina, E., 2015. Structural cause of a missed eruption in the Harrat Lunayyir basaltic field (Saudi Arabia) in 2009. Geology 43 (5):395-398. https://doi.org/10.1130/G36271.1.

Koulakov, I., Abkadyrov, I., Arifi, N., Deev, E., Droznina, S., Gordeev, E., Jakovlev, A., Khrepy S., Kulakov, R., Kugaenko, Yu., Novgorodova, A., Senyukov, S., Shapiro, N., Stupina, T. West, M., 2017. Three different types of plumbing systems beneath the neighboring active volcanoes of Tolbachik, Bezymianny and Klyuchevskoy in Kamchatka. J. Geophys. Res. Solid Earth 122 (5):3852-3874. https://doi.org/10.1002 2017JB014082.

Kozhurin, A., Zelenin, E., 2017. An extending island arc: the case of Kamchatka Tectonophysics 706-707:91-102. https://doi.org/10.1016/j.tecto.2017.04.001.

Kugaenko, Yu.A., Saltykov, V.A., Gorbatikov, A.V., Stepanova, M.Y., Abkadyrov, I.F., 2011. New data on the deep structure of the northern break of the Great Tolbachik fissure eruption (1975-1976). Dokl. Earth Sci. 441 (2), 1673-1677.

Kugaenko, Yu.A., Saltykov, V.A., Gorbatikov, A.V., Stepanova, M.Yu., 2013. Deep structure of the north vent area, Great Tolbachik fissure eruption of 1975-1976, Kamchatka: evidence from low-frequency microseismic sounding. J. Volcanol. Seismol. 7 (5), 313-327.

Kugaenko, Yu., Titkov, N., Saltykov, V., 2015a. Constraints on unrest in the Tolbachik volcanic zone in Kamchatka prior the 2012-13 flank fissure eruption of Plosky Tolbachik volcano from local seismicity and GPS data. J. Volcanol. Geotherm. Res. 307:38-46. https://doi.org/10.1016/j.jvolgeores.2015.05.020.

Kugaenko, Yu.A., Titkov, N.N., Saltykov, V.A., Voropaev, P.V., 2015b. An analysis of precursory phenomena for the 2012-2013 Tolbachik fissure eruption: seismicity parameters and crustal strain as inferred from data supplied by the system of multidisciplinary monitoring of volcanic activity in Kamchatka. J. Volcanol. Seismol. 9 (4), 258-275.

Kugaenko, Yu.A., Saltykov, V.A., Gorbatikov, A.V., Stepanova, M.Yu., 2018. Deep structure of the zone of Tolbachik fissure eruptions, Kamchatka, Klyuchevskoy Volcano Group: evidence from a complex of geological and geophysical data. Izv. Phys. Solid Earth 54 (3). https://doi.org/10.1134/S1069351318030059 (in press).

Laverov, N.P. (Ed.), 2005. Modern and Holocene Volcanism in Russia. Nauka, Moscow (604 p).

Lee, C.-T.A., Lee, T.C., Wu, C.-T., 2014. Modeling the compositional evolution of recharging evacuating, and fractionating (REFC) magma chambers: implications for differentiation of arc magmas. Geochim. Cosmochim. Acta 143, 8-22.

Lundgren, P., Kiryukhin, A., Milillo, P., Samsonov, S., 2015. Dike model for the 2012-2013 Tolbachik eruption constrained by satellite radar interferometry observations. J. Volcanol. Geotherm. Res. 307, 79-88.

Macdonald, G.A., 1972. Volcanoes. Prentice-Hall, Englewood Cliffs, N.J (510 pp).

Martí, J., Pinel, V., López, C., Geyer, A., Abella, R., Tárraga, M., Blanco, M.J., Castro, A. Rodríguez, C., 2013. Causes and mechanisms of the 2011-2012 El Hierro (Canary Islands) submarine eruption. J. Geophys. Res. Solid Earth 118:823-839. https://doi. org/10.1002/jgrb.50087.

McGee, L.E., Millet, M.A., Beier, C., Smith, I.E., Lindsay, J.M., 2015. Mantle heterogeneity controls on small-volume basaltic volcanism. Geology 43 (6), 551-554.

Melekestsev, I.V., Khrenov, A.P., Kozhemyaka, N.N., 1991. Tectonic position and genera description of volcanoes of northern group and Sredinny range. In: Fedotov, S.A Masurenkov, Yu.P. (Eds.), Active Volcanoes of Kamchatka. vol. 1. Nauka, Moscow, pp. $74-81$.

Nakamura, K., 1977. Volcanoes as possible indicators of tectonic stress orientation-principle and proposal. J. Volcanol. Geotherm. Res. 2 (1):1-16. https://doi.org/10.1016/ 0377-0273(77)90012-9.
Nemeth, K., Kereszturi, G., 2015. Monogenetic volcanism: personal views and discussion. Int. J. Earth Sci. 104, 2131-2146.

Ozerov, A.Y., Ariskin, A.A., Barmina, G.S., 1996. The problem of genetic relations between high-aluminous and high-magnesian basalts of the Klyuchevskoi volcano. Kamchatka. Trans. Russ. Acad. Sci. Earth Sci. Sect. 350 (7), 1127-1130.

Pallister, J.S., McCausland, W.A., Jonsson, S., Lu, Z., Zahran, H.M., El-Hadidy, S.Y., Aburukbah, A., Stewart, I.C.F., Lundgren, P.R., White, R.A., Moufti, M.R.H., 2010. Broad accommodation of rift-related extension recorded by dyke intrusion in Saudi Arabia. Nat. Geosci. 3 (10), 705.

Passarelli, L., Rivalta, E., Shuler, A., 2014. Dike intrusions during rifting episodes obey scaling relationships similar to earthquakes. Sci. Rep. 4, 3886. https://doi.org/10.1038/ srep03886.

Portnyagin, M., Bindeman, I., Hoernle, K., Hauff, F., 2007. Geochemistry of primitive lavas of the Central Kamchatka Depression: magma generation at the edge of the Pacific Plate. In: Eichelberger, J., Gordeev, E., Izbekov, P., Kasahara, M., Lees, J. (Eds.), Volcanism and Subduction: The Kamchatka Region. 172. AGU Geophys. Monogr.: pp. 203-244. https://doi.org/10.1029/172GM16.

Portnyagin, M., Duggen, S., Hauff, F., Mironov, N., Bindeman, I., Thirlwall, M., Hoernle, K., 2015. Geochemistry of the Late Holocene rocks from the Tolbachik volcanic field, Kamchatka: towards quantitative modeling of subduction-related open magmatic systems. J. Volcanol. Geotherm. Res. 307, 133-155.

Scholl, D.W., 2007. Viewing the tectonic evolution of the Kamchatka-Aleutian (KAT) connection with an Alaska crustal extrusion perspective. In: Eichelberger, J., Gordeyev, Y., Izbekov, P., Kasahara, M., Lees, J.M. (Eds.), Volcanism and Subduction: The Kamchatka Region. 172. AGU Geophys. Monogr., pp. 3-35.

Sigmarsson, O., Karlsson, H.R., Larsen, G., 2000. The 1996 and 1998 subglacial eruptions beneath the Vatnajökull ice sheet in Iceland: contrasting geochemical and geophysical inferences on magma migration. Bull. Volcanol. 61 (7), 468-476.

Sigmundsson, F., Hooper, A., Hreinsdóttir, S., Vogfjörd, K.S., Ófeigsson, B., Heimisson, E.R., Dumont, S., Parks, M., Spaans, K., Guðmundsson, G.B., Drouin, V., Árnadóttir, T., Jónsdóttir, K., Gudmundsson, M.T., Högnadóttir, T., Friðriksdóttir, H.M., Hensch, M., Einarsson, P., Magnússon, E., Samsonov, S., Brandsdóttir, B., White, R.S., Ágústsdóttir, T., Greenfield, T., Green, R.G., Hjartardóttir, A.R., Pedersen, R., Bennett, R., Geirsson, H., LaFemina, P., Björnsson, H., Pálsson, F., Sturkell, E., Bean, C.J., Möllhoff, M., Braiden, A., Eibl, E.P.S., 2015. Segmented lateral dyke growth in a rifting event at Bar [eth] arbunga volcanic system, Iceland. Nature 517 (7533):191-195. https://doi.org/10.1038/nature14111.

Smirnov, V.S., 1979. The geoelectric section in the New Tolbachik volcanoes area. J. Volcanol. Seismol. 2, 21-27 (in Russian with English abstract).

Smith, I.E.M., Nemeth, K., 2017. Source to surface model of monogenetic volcanism: a critical review. In: Nemeth, K., Carracso-Nunez, G., Aranda-Gomez, J.J., Smith, I.E.M. (Eds.), Monogenetic Volcanism. 446. Geol. Soc. Lond. Spec. Publ.:pp. 1-28. https:// doi.org/10.1144/SP446.14.

Sun, S.S., McDonough, W.F., 1989. Chemical and isotopic systematic of oceanic basalts; implications for mantle composition and processes. Geol. Soc. Lond. Spec. Publ. 42, 313-345.

Takada, A., 1994. The influence of regional stress and magmatic input on styles of monogenetic and polygenetic volcanism. J. Geophys. Res. Solid Earth 99 (B7), 13563-13573.

Tarakanovsky, A.A., 1978. Areal volcanism of Kluchevskoy Dol, some structural features. Bull. Volcanologicheskih Stancii 54, 61-67 (In Russian).

Tatsumi, Y., Kogiso, T., Nohda, S., 1995. Formation of a third volcanic chain in Kamchatka: generation of unusual subduction-related magmas. Contrib. Mineral. Petrol. 120, 117-128.

Tsukanov, A.A., Gorbatikov, A.V., 2015. Microseismic sounding method: implications of anomalous Poisson ratio and evaluation of nonlinear distortions. Izv. Phys. Solid Earth 51 (4), 548-558.

Vazheevskaya, A.A., 1966. To the question of areal volcanism of Kamchatka. Modern Volcanism. Nauka, Moscow, pp. 66-68 (in Russian)

Vazheevskaya, A.A., 1979. Pecularities of areal volcanism of Kamchatka. Problemy Glubinnogo Volcanisma. Nauka, Moscow, pp. 97-108 (in Russian).

Vlodavets, V.I., 1971. About areal and multivent volcanism. In: Vlodavets, V.I. (Ed.), Volcanism, Hydrotermy i Glubiny Zemli, p. 23 (Petropavlovsk-Kamchatsky (in Russian)).

Volcanoes of Kurile-Kamchatka Island Arc - VOKKIA, d. Holocene volcanism of Kamchatkahttp://geoportal.kscnet.ru/volcanoes/geoservices/hvolc.php.

Volynets, A., Kugaenko, Yu, 2015. Integration of geochemical, petrological and seismic data for the study of volcanic plumbing system of the 1975-76 Tolbachik fissure eruption. Abstracts of 26th General Assembly of the International Union of Geodesy and Geophysics (IUGG), Prague, Czech Republic, VS28

Volynets, O.N., Flerov, G.B., Andreev, V.N., Popolitov, E.I., Abramov, V.A., Petrov, L.P., Scheka, S.A., 1978. Petrochemistry, geochemistry and problems of genesis of rocks of the 1975-76 Great Tolbachik fissure eruption. Dokl. Akad. Nauk SSSR 238 (4), 940-943 (in Russian).

Volynets, O.N., Flerov, G.B., Andreev, V.N., Popolitov, E.I., Abramov, V.A., Petrov, L.L., Shcheka, S.A., Selivanova, G.I., 1983. Geochemical features of the rocks of the Great Tolbachik fissure eruption 1975-1976 in relation to petrogenesis. In: Fedotov, S.P., Markhinin, Ye K. (Eds.), The Great Tolbachik Fissure Eruption: Geological and Geophysical Data 1975-1976 Cambridge Earth Science Series. Cambridge University Press, Cambridge, pp. 116-140.

Volynets, O.N., Babanskii, A.D., Gol'tsman, Y.V., 2000. Variations in isotopic and trace element composition of lavas from volcanoes of the northern group, Kamchatka, in relation to specific features of subduction. Geochem. Int. 38 (10), 974-989.

Volynets, A., Edwards, B., Melnikov, B., Yakushev, A., Griboedova, I., 2015. Monitoring of the volcanic rock compositions during the 2012-2013 fissure eruption at Tolbachik volcano, Kamchatka. J. Volcanol. Geotherm. Res. 307:120-133. https://doi.org/ 10.1016/j.jvolgeores.2015.07.014 
Walker, G.P., 1993. Basaltic-volcano systems. Geol. Soc. Lond. Spec. Publ. 76 (1), 3-38 Williams, H., 1950. Volcanoes of the Paricutin region, Mexico. U.S. Geol. Den. Surv. Bull. 965-B, 165-279.

Williams, H., McBirney, A.R., 1979. Volcanology. Freeman, Cooper, San Francisco, California (397 pp).

Zobin, V.M., Al-Amri, A.M., Fnais, M., 2013. Seismicity associated with active, new-born, and re-awakening basaltic volcanoes: case review and the possible scenarios for the Harraat volcanic provinces, Saudi Arabia. Arab. J. Geosci. 6 (2):529-541. https:// doi.org/10.1007/s12517-011-0379-3.

Zubin, M.I., Tarakanovski, A.A., 1976. Tektonika i osobennosti polia sily tyazhesti raiona Klyuchevskoy gruppi vulcanov. Glubinnoe stroenie, seismichnost i sovremennaya deyatelnost Klyuchevskoy gruppi vulcanov. Vladivostok. pp. 17-28 (in Russian). 